\title{
Modeling of PCB trophic transfer in the Gulf of Lions; 3D coupled model application
}

\author{
Alekseenko Elena ${ }^{1,2,{ }^{*}}$, Thouvenin Benedicte ${ }^{4}$, Tronczynski Jacek ${ }^{5}$, Carlotti F. ${ }^{6}$, Garreau Pierre ${ }^{3}$, \\ Tixier Celine, Baklouti Melika ${ }^{6}$
}

${ }^{1}$ Russian Acad Sci RAS, PP Shirshov Inst Oceanog, SIO, Nakhimosyskiy 36, Moscow 117218, Russia.

${ }^{2}$ CEA Saclay, IPSL, LSCE, F-91191 Gif Sur Yvette, France.

3 Univ Brest, IFREMER, CNRS UMR 6523, IRD,LOPS,IUEM, F-29280 Brest, France.

${ }^{4}$ IFREMER, Dynam Ecosyst Cotiers, BP70, F-29280 Plouzane, France.

${ }^{5}$ IFREMER, RBE BE LBCO, BP 21105, F-44311 Nantes, France.

${ }^{6}$ Univ Toulon \& Var, Aix Marseille Univ, CNRS, INSU,IRD,MIO,UM 110, F-13288 Marseille 09, France.

* Corresponding author : Elena Alekseenko, email address : elena.alekseenko@lsce.ipsl.fr

\begin{abstract}
:
3D coupled modeling approach is used for the PCB dispersion assessment in the Gulf of Lion and its transfer to zooplankton via biogeochemical processes. PCB budgets and fluxes between the different species of PCB: dissolved, particulate, biosorbed on plankton, assimilated by zooplankton, which are governed by different processes: adsorption/desorption, bacteria and plankton mortality, zooplankton excretion, grazing, mineralization, volatilization have been estimated. Model outputs were compared with the available in situ data.

It was found that the Rhone River outflows play an important role in the organism contamination in the coastal zone, whereas the atmospheric depositions are rather more important in the offshore zones. The transfer of the available contaminant to bacteria and phytoplankton species is mainly related to the biomass present in the water column. Absorption fluxes (grazing) to zooplankton are rather higher than the passive sorption fluxes, which are themselves also linked to the sorption coefficient.
\end{abstract}

Keywords : PCBs, 3D coupled model, Gulf of Lions, Planktonic food web, CB153 fluxes 


\section{Introduction}

Awareness of hazardous chemical contamination have seen increasing in the recent years. Chemicals enter the environment from industrial effluents, disposal, transport and a wide variety of uses in products. As a result, persistent organic pollutants (POPs) have now reached all corners of the world, contaminating humans and animals.

Marine ecosystems play a major role as a sink for chemical pollutants. It is known, that the Mediterranean Sea is the largest semi-enclosed sea and is surrounded by heavily industrialized and agricultural countries all around its basin. Throughout the last decades, industrial, agricultural and urban wastes have been discharged into the Mediterranean via rivers and the atmosphere, causing a considerable increase in pollution of the marine ecosystem (UNEP, 1996, 2002). Moreover due to the fact that the semienclosed Mediterranean Sea has a limited water exchange with the Atlantic ocean through the strait of Gibraltar, it is highly sensitive to the build-up of pollutants (UNEP, 1996, 2002) that may cause a progressive degradation of its marine ecosystem. Polychlorinated biphenyls (PCBs) are often used as model compounds to study the environmental behaviour of POPs (Schuster et al., 2010 ; De Laender et al., 2010). These highly toxic chemical pollutants were extensively used in industry in the last century. Even being banned for decades, PCBs are still found in the majority of aquatic sediments and accumulate in the trophic webs (Falandysz et al., 2004; Lanfranchi et al., 2006).

Since PCBs are hydrophobic, the carbon cycle has a key role in controlling environmental transfer of PCBs to the higher trophic levels. Uptake by highly dynamic organic carbon pools, such as bacteria and plankton, may influence chemical concentrations in water, thereby affecting the magnitude of PCBs advection and long-term bioaccumulation.

Various studies (Nizzetto et al , 2012, Sobek et al, 2004, Wallberg et al, 1997) showed that the lower trophic levels, such as phytoplankton and bacteria, are only exposed to contaminants via water, therefore the bioaccumulation is governed by sorption between the cells and the surrounding water. For zooplankton feeding on them, two contamination pathways must be considered : diffusive exchanges and ingestion of contaminated food (Borga et al, 2005). However, there is few information on the PCB transfer to zooplankton actually occurring in the field (Tiano et al, 2014, Cailleaud et al, 2007, Lynn et al, 2007, Magnusson et al, 2006). Such information is crucial 
to make reliable predictions about PCB transfer to the higher trophic levels.

This work aims at assessing the role of plankton in the transfer of PCBs to higher trophic levels in the Gulf of Lions (NW Mediterranean Sea) using a 3D modelling approach, which is coupling biogeochemical and hydro dynamical processes and taking into account the physical-chemical properties of PCBs. The coupling of biogeochemical, ecological and hydrodynamical processes and a better understanding of the buffer or amplifier role of plankton in the transfer of organic contaminants to higher trophic levels are our research objectives.

Modeling is a powerful tool for coupling processes under different disciplines and scales. The lack of detailed observations in the sea and the significant uncertainty about the sources of contaminants prevent from a proper validation of models that describe fine temporal and spatial scales; the interest of these models is thus a priori limited (Wania and Mackay, 1995). However, such models are interesting to explore the influence of fast processes on the transfer of contaminants to bioaccumulative species.

A coupled three-dimensional model for the assessment of PCB dispersion in space and time and of its transfer to zooplankton via biogeochemical processes have been developed for this purposes. The sediment transport and PCBs transfer models were coupled with the 3D physical-biogeochemical model MARS3D/Eco3M-MED (Alekseenko et al. 2014). Transport of various $\mathrm{PCB}$ species were simulated during one year : total dissolved, truly dissolved, particulate, biosorbed on plankton, assimilated by zooplankton. PCB budgets and fluxes into the Gulf of Lions between various species were governed by different processes, such as : adsorption/desorption, bacteria and plankton mortality, zooplankton excretion, grazing, mineralization, volatilization and biodegradation. CB153 (2,2',4,4',5,5' hexachlorobiphényle) congener have been considered in the model, since it presents a large amount of PCB among the other congeners in the environment of the Gulf of Lions.

At first, in the Section 3, the simulated PCBs distributions within particulate matter and plankton were compared with available in-situ measurements (COSTAS and Merlumed field campaigns) performed in the Gulf of Lions. Two size classes of plankton $\mathrm{X}(60 \mu \mathrm{m}<\mathrm{X}<200 \mu \mathrm{m}$ and $200 \mu \mathrm{m}<\mathrm{X}<500 \mu$ $\mathrm{m})$ and suspended solids have been considered for the comparison. Then, the analyses of spatio-temporal variations of $\mathrm{PCB}$ within different compartments have been performed in order to advance in understanding the contamination pathways from air and water to plankton. Processes influencing PCB transfer were thereby analyzed : (i) physical and chemical processes, such as 
riverine and atmospheric inflow, volatilization, sorption and suspension and (ii) biogeochemical processes, namely grazing, mortality, mineralization and excretion.

\section{Model description}

A coupled three-dimensional model for the assessment of PCB dispersion in space and time have been developed. Specifically, the hydrodynamicalbiogeochemical model MARS3D/Eco3M-MED was coupled with models of sediment and PCB transport fluxes. The new developed model hereafter will be referred as MARS3D/Eco3M-MED-PCB coupled model.

The spatial configuration used in this study covers Gulf of Lions (GoL) $\left(39.50^{\circ} \mathrm{N}, 44.50^{\circ} \mathrm{N} / 0.00^{\circ} \mathrm{E}, 16.00^{\circ} \mathrm{E}\right)$ with a horizontal resolution of $1.2 \mathrm{~km}$ $\left(1 / 16^{\circ}\right)$ (Fig. 1). At the southern and eastern boundaries of the domain, the boundary conditions in biogeochemical variables, temperature, salinity, current and free surface elevation are provided by the MENOR configuration of MARS3D/Eco3M-MED covering NW Mediterranean Sea (Alekseenko et al., 2014). In Alekseenko et al. (2014) the authors discuss the meteorological forcings and boundary conditions forcing the MENOR configuration as well as Rhone river discharges taken into account.

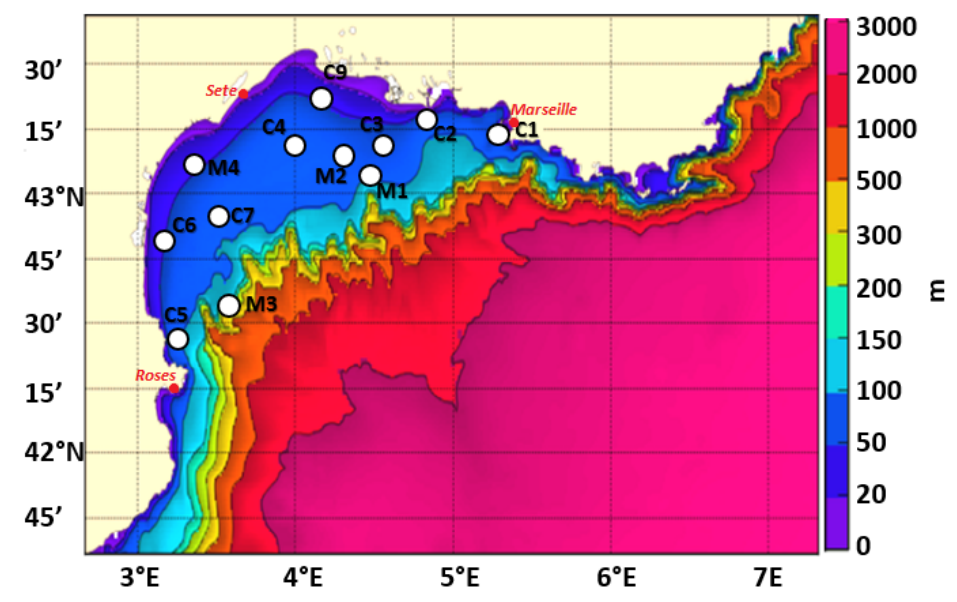

Figure 1: GoL bathymetry $(\mathrm{m})$ relative to mean level with measuring stations (C1-C9 from COSTAS field campaign and M1-M4 from MERLUMED field campaign). 


\subsection{Hydrodynamic model}

The hydrodynamical model used in this study is MARS3D (3D Model for Applications at Regional Scale) developed by Ifremer. This model solves the incompressible Navier-Stokes equations based on the hydrostatic and Boussinesq approximations (Blumberg and Mellor, 1987 Lazure and Dumas, 2008). It uses sigma coordinates and has the particularity of using a common time step to resolve the baroclinic and barotropic modes, based on the alternating direction implicit scheme (Lazure and Dumas 2008; Schaeffer et al. 2011). A complete description of this model is given in the publication of Lazure and Dumas (2008).

The hydrodynamical model was validated for the Gulf of Lions comparing the main characteristics of the simulated shelfslope circulation (e.g., mesoscale structures as well as salinity and temperature distributions) with (1) in situ (André et al. 2009) and (2) satellite (André et al. 2005) observations, as well as with (3) satellite observations and drifter trajectories in the Gulf of Lions by Nicolle et al. (2009). These previous studies have demonstrated the ability of the GoL model to compute hydrodynamic processes and patterns with sufficient accuracy for being coupled with a biogeochemical model. Hydrodynamic processes such as horizontal and vertical advection or mixing are indeed essential features in the control of marine biogeochemistry, as they strongly influence light and nutrient availability in the upper layer of the ocean (Oschlies and Garçon 1999; Doney et al. 2004). Vertical motions associated with upwelling also play an important role in the heterogeneity of nutrient inputs in the mixed layer and in the photic zone. These inputs trigger localized phytoplankton blooms (Levy 2003; The MerMex Group et al. 2011), which, in turn, trigger a biological response in the higher trophic levels of the marine food web.

\subsection{Hydrosedimentary model}

The hydrosedimantary model incorporated into MARS3D (Dufois et al., 2008 ) is based on developments made in past years on the SiAM3D model (Le Hir et al. , 2011, Waeles et al., 2007, 2008). In this simplified version, simulated suspended particulate matter (SPM) sink into three categories : SPM representing fine sediment issued from the Rhone River, SPM representing organic aggregates (associated with carbon, nitrogen and particulate phosphorus) and SPM associated with the residual turbidity of surface water (supplied by atmospheric deposition). The sand brought by the Rhone is not supposed to carry a large flow of contaminant and is not simulated in this 
model. Processes of deposition and erosion are reproduced (Verney et al., 2013, Le Fouest et al., 2015). The original sedimentary cover is made zero that is to say at the outset of the simulation, there is no sediment deposited at the bottom. Flow erosion of old sediment (contaminated or not), and the diffusive flux of dissolved contaminants from early diagenesis are not taken into account in the model.

The model considers only a single stock of particulate organic matter to represent the mud from the Rhone, and detrital organic material obtained from planktonic mortality or from mesozooplankton excretion. This is a rough approximation since the muds from the Rhone might have a sinking rate much greater than the detrital organic material itself can have quite variable sinking rates according to its origin. The sinking rates of the three classes were first made low : $0.008 \mathrm{~mm} / \mathrm{s}$ for particulate organic matter and 0,001 $\mathrm{mm} / \mathrm{s}$ for particulate matter contributed by atmospheric deposition.

\subsection{Biogeochemical model}

The hydrodynamic model MARS3D was coupled to the biogeochemical model Eco3M-MED (Alekseenko et al., 2014).

Eco3M-MED was built using Eco3M (Ecological Modular Mechanistic Modeling tool) biogeochemical modeling platform, developed by MIO (Mediterranean Institute of Oceanography) discussed in Baklouti et al. (2006a, b), Baklouti et al. (2011), Alekseenko et al. (2014). Eco3M has a modular structure (e.g., Baklouti et al. 2006b; 2011; Fontana et al. 2009 ; Auger et al. 2011, Alekseenko et al. 2014), what means that models with different plankton functional types (PTFs) or size-structured populations (Eisenhauer et al. 2009), as well as a flexible plankton stoichiometry can be elaborated (Baklouti et al. 2006a, b). A numerical library is also embedded in Eco3M that contains the mathematical functions of processes, mechanistic for most of them, used the successive Eco3M versions.

The Eco3M-MED model equations and features as well as its validation in the NW Mediterranean Sea was previously reported in detail by Alekseenko et al. (2014). One of the advantage of Eco3M-MED model is that functional groups were represented both in terms of biomasses and abundances (Mauriac et al. 2011), allowing to deliver average biomass per individual. The introduction of abundances enables for example a direct comparison (i.e., without using a conversion factor) of the model outputs with the growing data set of bacteria, phytoplankton or zooplankton abundance that are provided by recent techniques such as flow cytometry or zooplankton counters. It also 
makes it possible to differentiate between cell division and biomass synthesis in the model. Eco3M-MED model is based on the assumption that for each organism, the intracellular or individual X content (where X stands for $\mathrm{C}, \mathrm{N}$, or $\mathrm{P}$ ) must be comprised within minimum and maximum quotas (Baklouti et al., 2006 a,b ; Alekseenko et al., 2014). In addition these internal quotas are calculated dynamically for each organism and contribute to the regulation of the kinetics of many physiological processes included in the model. The use of a biogeochemical model with flexible stoichiometry is particularly suitable for studies of the Mediterranean Sea since, depending on the season and the geographical position, $\mathrm{N}$ and/or $\mathrm{P}$ can limit primary production, and because of the specificity of this sea in terms of N/P stoichiometry (e.g., Pujo-Pay et al. 2011).

Biogeochemical model Eco3M-MED take into account non-living and living compartments (12 in all), namely : nutriments (nitrates, phosphates and ammonium), particulate and dissolved (labile and semilabile) organic matter, bacteria, two size classes of phytoplankton (more and less than $10 \mu \mathrm{m}$ ) and three size classes of zooplankton (nano-, micro- and mesozooplankton). Each compartment (except nutrients) is expressed in terms of nitrate, phosphor and carbon biomass, in addition, living matter is represented also in terms of abundances, phytoplankton is also expressed in terms of chlorophyll concentration.

MARS3D/Eco3M-MED coupled model was previously applied in Alekseenko et al. (2014) for studies of the seasonal spatio-temporal dynamics of functional groups in the NW Mediterranean Sea. It was shown that the coupled model captures the main well-known characteristics of the Mediterranean ecosystem. A good agreement was found between the model outputs and various available data, including measured in situ horizontal and vertical distributions of chlorophyll-a and nutrients. Therefore, such a coupled model is appropriate to be applied for the contaminant transfer studies of through its trophic chain.

\subsection{PCB transfer model}

Behavior and the presence of PCBs in aquatic environments depend on ocean biogeochemical cycles. This involves several biological processes such as bioaccumulation, growth, sinking particles or biodegradation (Jurado et al., 2004).

The hydrophobic organic compounds such as PCBs, are known to be associated with the organic material (Totten et al., 2001). Thus, the PCB 
transport model is based on the assumption that the transfer of PCBs between the considered various compartments and species are proportional to carbon transfers, which are themselves related to biogeochemical processes simulated by the model Eco3M-MED.

Four types of PCBs are considered in the model : (i) PCB dissolved inorganic form, (ii) dissolved PCB associated with dissolved organic matter (DOM), (iii) PCB associated with particulate organic detrital matter (POM) and (iv) PCB associated with living matter.

The basic assumptions of the model of transport and transfer of PCB are as follows (Fig.2) :

- PCB flows through the food chain are connected to the biogeochemical carbon fluxes due to process i) grazing ii) mortality, iii) mineralization iv) excretion and adsorption/desorption fluxes (or passive sorption).

- There are two ways of PCB accumulation by plankton : i) passive sorption (for phyto and zooplankton, "PCBq") and ii) absorption by assimilation due to grazing of contaminated prey (only for zooplankton, "PCB").

- Passive sorption processes are supposed to work towards an equilibrium that is governed by partition coefficients $\left(\mathrm{K}_{o c}\right)$ normalized by the carbon content.

\section{Passive sorption processes}

Passive sorption processes (adsorption / desorption) are treated as reactions dealing with the equilibrium sharing of several variables that undergo a rapid reversible reactions.

The experimental results on the rates of desorption of PCBs associated to suspended matter provided by Gong et al (1998) showed that the assumption of a steady state reached very quickly is questionable. In fact, according to Ball and Roberts (1991), the desorption process can take several days, weeks

or years. Thus, a kinetic approach to simulate the process of desorption of PCBs from materials in suspension is preferable (Gong et al, 1997, Cheng et al, 1994). Gong et al (1997) reported that the kinetics of this process in natural environments may be different from that observed in short-term experiments in the laboratory, the time to reach equilibrium sorption are very different. According to the desorption experiments of Gong et al (1997) for the CB153, the time of equilibration vary between 20 and 72 days. On the other hand, Del Vento and Dachs (2002) and Cheng-Wei Fan and Reinfelder. (2003), who worked on the sorption kinetics for living organisms : phytoplankton and bacteria, found that equilibrium is achieved only at the end 
of several days or weeks, which is in contradiction with the assumption of instant sharing, resulting from a balance reached very quickly. The duration of the desorption process is related to the time required for the diffusion of the contaminant through the solid matrix (intraparticle diffusion, Bold et al., 2003).

Thus, the adsorption/desorption process in the model is described by a process in agreement with sorption coefficients and desorption kinetic rate. The total "exchangeable" PCB concentration $\left(C_{\text {totalPCB }}: \mathrm{Eq} 1\right)$ consisting of various active variables (or "exchangeable" species of a contaminant) is equal to the sum of their concentrations :

$$
C_{\text {totalPCB }}=C_{d l}+C_{d}+\sum_{i} C_{p}(i) .
$$

In $\mathrm{Eq} 1 C_{d l}$ is the concentration of the truly dissolved CB153, $C_{d}$ is associated with dissolved organic matter $(\mathrm{DOM})$, and $C_{p}(i)$ are concentrations of PCB, associated with particulate substrates (POM which includes nonliving and living matter). At equilibrium, $C_{d}^{e q}$ and $C_{p}(i)^{e q}$ depend on $C_{d l}^{e q}$ and organic carbon-normalized distribution coefficients : $K_{o c}$ (for particulate matter)and $K_{o d}$ (for dissolved matter) :

$$
C_{p}(i)^{e q}=K_{o c_{i}} \cdot P O M_{i} \cdot C_{d l}^{e q} ; C_{d}^{e q}=K_{o d} \cdot D O M \cdot C_{d l}^{e q} .
$$

The amount of sorbed contaminant on a given substrate (POM, DOM) which will effectively desorb at each time step depends on the desorption rate corresponding to the substrate and the deviation of the concentration from the equilibrium state defined by Eq. 2. Sorption parameters taken mostly from literature data and chosen for the modelling are summarized in the Table 1. Kinetic rate values for the different compartments have been chosen after various modelling tests.

TABLE 1: Sorption parameters

\begin{tabular}{|l|l|l|l|l|l|}
\hline & SPMVL & DOM & SPM (POM) & COP, CIL, HNF & PHYL, PHYS, BAC \\
\hline Log10 $(\mathrm{ml} / \mathrm{g})$ & 4.94 & 5.8 & 6.94 & 5 & 6 \\
\hline $\begin{array}{l}\text { References } \\
\text { and hypotheses }\end{array}$ & POM=1\%SPMVL & $\begin{array}{l}\text { Burkhard, 2000 (fig.1), } \\
K_{d}\end{array}$ & $\begin{array}{l}\text { COSTAS data, } \\
K_{o c}\end{array}$ & Wallberg et al, 1997 & Wallberg et al, 1997, \\
\hline Kinetic rate $\mu\left(d^{-1}\right)$ & \multicolumn{2}{|c|}{ equilibrium } & 4 & & 12 \\
\hline
\end{tabular}

\section{Volatilisation processes}


The air-water exchanges (volatilization) are one of the main pathways of entry and exit of PCBs in the marine environment (Galbán-Malagón et al, 2013). For hydrophobic congeners, such as CB153, which are mostly in particle form, the water - air exchange is relatively low. However for less hydrophobic congeners, the volatilization process may become more important.

Transfer to the air-water interface is calculated in the MARS3D/Eco3MMED-PCB model using the two layers approach of Liss and Slater (1974), which assesses the transfer coefficients in the liquid and gas relative to reference compounds phases. A number of parameters are necessary and several formulas are used to evaluate the exchanges in the liquid and gaseous phases.

According to the two-film volatilization model of Liss and Slater (1974), the interface between bulk water and air is bounded by a stagnant transition film on each side, across which the solute moves by diffusion. The respective film thicknesses depend on turbulence intensities in the respective phases. The solute concentrations in bulk water and air phases are considered to be essentially uniform, and thus the combined diffusive transport through the two stagnant films constitutes the principal volatilization resistance. The water-film and gas-film transfer resistances of a solute are related to the respective mass transfer coefficients, the latter being defined as :

$$
F=k_{l}\left(C_{l}-C_{l i}\right)=k_{g}\left(C_{g i}-C_{g}\right),
$$

where $F$ - mass transfer flow through the air-water interface by volatilization $\left(\mathrm{kg} / \mathrm{m}^{2} / \mathrm{s}\right), k_{l}$ - the liquid-film transfer coefficient $(\mathrm{m} / \mathrm{s}), k_{g}$ - the gas-film transfer coefficient $(\mathrm{m} / \mathrm{s}), C_{l}$ - the concentration in the bulk liquid $\left(\mathrm{kg} / \mathrm{m}^{3}\right), C_{l i}$ - the concentration at the liquid side of the interface $\left(\mathrm{kg} / \mathrm{m}^{3}\right)$, $C_{g i}$ - the concentration at the gas side of the interface $\left(\mathrm{kg} / \mathrm{m}^{3}\right)$, and $C_{g}$ - the concentration in the bulk air $\left(\mathrm{kg} / \mathrm{m}^{3}\right)$.

The compound passes from one phase to the other to reach the state of equilibrium. The phases are assumed to be in thermodynamic equilibrium at the interface (Lee et al., 2004) :

$$
C_{l i}=C_{g i} / H^{\prime}
$$

$H^{\prime}$ is the dimensionless Henry constant corresponding to the ratio of the gas concentration to the liquid concentration, both expressed in $\mathrm{mol} / \mathrm{m}^{3}$ $H^{\prime}=H /(R T)$. The Henry $H$ constant describes the volatility of a compound in air : $H\left(\mathrm{~m}^{3} \mathrm{~Pa} / \mathrm{mol}\right)$-(partial vapor pressure of the compound)/(aqueous 
concentration), $\mathrm{R}$ - universal gas constant $\left(\mathrm{Pa} \mathrm{m}^{3} / \mathrm{mol} / \mathrm{K}\right), \mathrm{T}$ - temperature $(\mathrm{K})$.

The combination of equations makes it possible to express the mass transfer flux $F$ as a function of the concentrations in the water layer $\left(C_{w}\right)$ and in the air $\left(C_{a}\right)$ layer (Achman et al., 1993) :

$$
F=K_{o l}\left(C_{w}-C_{a} / H^{\prime}\right), 1 / K_{o l}=1 / k_{l}+R T /\left(H k_{g}\right) .
$$

$K_{o l}$ is the total air-water transfer coefficient that incorporates the contributions of $k_{l}$ and $k_{g}$. Terms $1 / k_{l}$ and $1 / H^{\prime} k_{g}$ are the resistances in the liquid and gaseous phases respectively.

The dimensionless Henry constant $H^{\prime}$ depends on temperature according to formula of Staudinger et Roberts (2001) :

$$
H^{\prime}(T)=H^{\prime}\left(20^{\circ} C\right) 10^{-B(1 / T-1 / 293)},
$$

where $H^{\prime}\left(20^{\circ} C\right)-H^{\prime}$ at $20^{\circ} C, \mathrm{~B}$ - Staudinger coefficient $\left({ }^{\circ} \mathrm{K}\right)$.

Thus in the present work, the flux in the interface is proportional to the gradient between truly dissolved contaminant concentration in water and its concentration in the gas phase divided by the dimensionless Henry constant (Liss et Slater, 1974). The parameters used in this work are presented in Table 2. This process depends on the concentration of PCBs in the air which itself depends on the temperature. Since available at Cap Ferrat and Seynesur-mer (IFREMER, 2011) measurements show different profiles and do not identify a simple function of temperature (not shown), concentration in the air was therefore taken constant whatever the season and uniform over the entire area.

Parameters used in the Liss and Slater (1974) approach are following :

- Dimensionless Henry constant $\left(H^{\prime}\right)$ (Staudinger et Roberts, 2001, see Table 2) ;

- Transfer coefficient $\left(k_{g}\right)$ in the gas phase is evaluated from the mass transfer coefficient of reference compound $\mathrm{H}_{2} \mathrm{O}$, corrected by the inverse ratio of the square roots of molecular weights $\mathrm{M}: k_{g}(c)=$ $k_{g}\left(\mathrm{H}_{2} \mathrm{O}\right)\left(\mathrm{M}(\mathrm{c}) / \mathrm{M}\left(\mathrm{H}_{2} \mathrm{O}\right)\right)^{-0.5}$, with $k_{g}\left(\mathrm{H}_{2} \mathrm{O}\right)=(0.2 \mathrm{U} 10+0.3) / 100$ depends on wind speed U10 at 10 meters under the sea surface proposed by Schwarzenbach et al (1993) and used also by Achman et al (1993), Zhang et al (1999), Totten et al (2001);

- The transfer coefficient $k_{l}$ into the liquid phase is evaluated from the mass transfer coefficient of the reference compound $\mathrm{CO}_{2}$, cor- 
rected by the inverse ratio of square roots of molecular weights : $k_{l}(c)=k_{l}\left(C_{2}\right)\left(M(c) / M\left(C O_{2}\right)\right)^{-0.5} \cdot k_{l}\left(C O_{2}\right)$ is estimated by adding two terms : the first corresponds to the transfer due to the turbulence generated by the wind $\left(k_{l v}\right)$ and the second due to the turbulent diffusion $\left(k_{l d}\right) . k_{l v}$ increases approximately with the square of the wind speed (Liss, 1973, Shwartzenbach et al, 1993). $k_{l d}$ is estimated from the transfer coefficient of oxygen $k_{l}\left(\mathrm{O}_{2}\right)$, corrected by the ratio of the square roots of molecular diffusivity. Churchill formula is used to evaluate $k_{l}\left(O_{2}\right)=5.8 e-5 * U^{0.969} / z^{0.673}$ (Churchill et al 1962 in Wilcock, 1982 ) with $\mathrm{U}$ - water current and $\mathrm{z}$ immersion.

TABLE 2: Volatilization parameters

\begin{tabular}{|l|l|}
\hline Parameter & Value \\
\hline$C_{\text {air }}$ & $2 \mathrm{pg} / \mathrm{m}^{3}$ \\
Henry constant, $H^{\prime}$ & $8.09 \mathrm{e}-3$ \\
Staudinger constant, B & 4104 \\
\hline
\end{tabular}

\subsection{Coupled model description}

Therefore, the conceptual scheme of the developed model Eco3M-MEDPCB (coupled with the hydrosedimentary model MAR3D) used in this study accounting the complex food-web of the NW Mediterranean Sea is represented on the Fig. 2. Compared to the previous version of the conceptual scheme of Eco3M-MED described in Alekseenko et al. (2014), a PCB biomass is taken into account in the planktonic food web. Therefore, the coupled model MARS3D/Eco3M-MED-PCB contains 52 state variables in addition to the hydrodynamic variables, salinity and temperature :

- The nutrient concentrations and inorganic truly dissolved PCB ( $\left.\operatorname{Diss}_{P C B q}\right)$;

- The labile dissolved organic matter characterized by its content of carbon, nitrogen and phosphorus, the semi-labile organic matter characterized by its carbon content, the $\mathrm{PCB}$ associated with the total dissolved organic matter $\left(\mathrm{DOM}_{P C B q}\right)$;

- Particulate organic matter $(\mathrm{POM})$ and mineral suspended particles (SPM) inputs from the Rhone, a fraction of very light material constituting the background noise and from atmospheric deposition supposed suspension (SPMVL) and PCB concentrations associated with this material $\left(\mathrm{SPMVL}_{P C B q}, \mathrm{POM}_{P C B q}\right)$; 
- Bacterial cells (BAC) with the content of carbon, nitrogen and phosphorus and $\mathrm{PCB}\left(\mathrm{BAC}_{P C B q}\right)$

- Two groups of phytoplankton cells representing two size classes $(<10 \mu \mathrm{m}$ $(\mathrm{S}$, small) and $>10 \mu \mathrm{m}$ (L, large), respectively designated PHYS and PHYL) with their carbon, nitrogen, phosphorus, chlorophyll and PCB content( PHYS $_{P C B q}$, PHYL $\left._{P C B q}\right)$;

- Three zooplankton groups representing three size classes : nano-, microand mesozooplankton. For each size class, the most abundant species in the NW Mediterranean was chosen, namely : 1) nanozooplancton - heterotrophic nanoflagellates (HNF), 2) microzooplankton - ciliates (CIL) and 3) mesozooplankton - copepods (COP). Each group of zooplankton is characterized by its abundance in cells, the contents of carbon, nitrogen and phosphorus. There are two species of associated PCB within each zooplankton organism : one adsorbed (PCBq), and another one coming by grazing $(\mathrm{PCB})\left(\mathrm{HNF}_{P C B q}, \mathrm{HNF}_{P C B}\right.$, $\left.\mathrm{CIL}_{P C B q}, \mathrm{CIL}_{P C B}, \mathrm{COP}_{P C B q}, \mathrm{COP}_{P C B}\right)$.

The simulation period covers 12.5 months starting from 15/12/2009. The initial date have been chosen in order to take into account Rhone River flooding event (see Fig. 3).

\section{Forcings}

The forcings of the hydrodynamic and biogeochemical model were presented in detail in Alekseenko et al (2014). Forcings for specific contaminants are described in Table 3, they concern :

- intakes of PCB by the Rhone in dissolved and particulate form,

- dry and wet (rain) PCB atmospheric deposition

- PCB introduced into the area by the open boundary conditions in the southern and eastern open boundaries of GoL.

Concerning the PCB outflow by the Rhone River, ARCMED data(Tronczynski et al, 2012, their Fig.4) was used to assess PCB associated to suspended matter and dissolved matter. In this work concentrations of PCB are constantly proportional to carbon coming with Rhone River outflows in dissolved and particulate form. For this purpose, Rhone River discharge time series measured in Arles station by Systeme d'Information sur l'Eau (http ://sierm.eaurmc.fr), as well as SPM concentration time series measured in station SORA (INSU source) have been used (Fig. 3).

Atmospheric transport and deposition are the mechanisms responsible for the PCB contamination in the open sea (Jurado et al, 2004). PCBs can be 


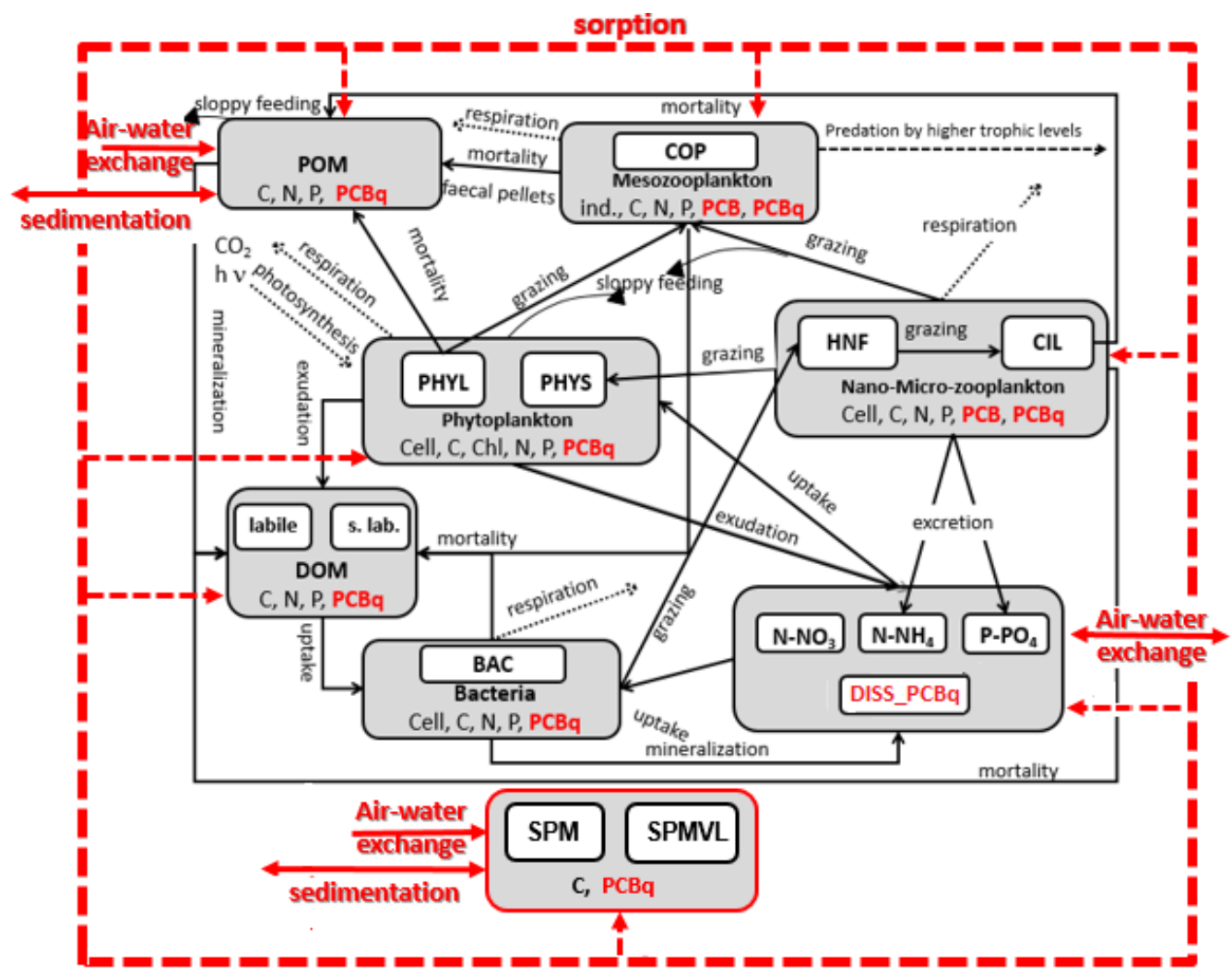

FiguRE 2: Basic schema of biogeochemical model Eco3M-MED-PCB.

delivered to the long distances by the atmosphere and contaminate terrestrial and aquatic ecosystems in a large scale (Berrojalbiz et al, 2014). The measurement difficulties, associated mainly with the high analysis costs, limit the amount of available data on the PCB concentrations in the atmosphere at any studied location. These constraints with the scarce available database present one of the main problem for the PCB transfer modelling to accurately estimate atmospheric forcings and also in a validation step (Castro-Jimenez et al, 2009). Different available data are used to force models : measured in fixed stations or during local and regional field campaigns; obtained in the national or international surveyance networks in the larger scale. Unfortunately, few data on atmospheric PCB concentrations is available for the GoL and its neighbor regions. Therefore to evaluate the PCB atmospheric dry and wet deposition measurements reported by Castro-Jimenez et al (2009, 2011) at the sub-alpine and northern Italy and at the Etang de Thau region 


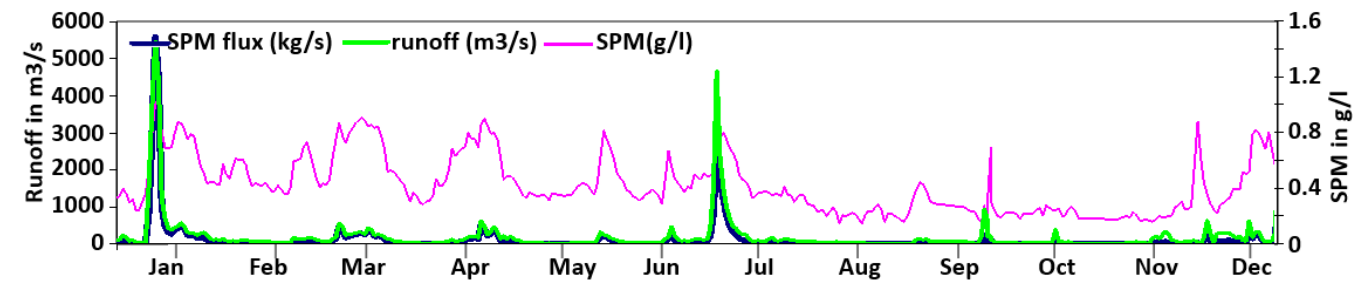

Figure 3: Rhone runoff (measured in Arles station by Systeme d'Information sur l'Eau http ://sierm.eaurmc.fr), concentration in SPM (measured in station SORA, INSU source) and resulting flux of SPM for the simulated period.

have been used. The principal hypotheses associated to the atmospheric dry and wet depositions considered in the present model are summarized in the Table 3.

The initial and open boundary conditions for total exchangeable PCB and for PCB associated to zooplankton are described in Table 3. It is considered that at the beginning of the simulation and on the open boundaries, partition of total exchangeable PCBq between all species is at equilibrium. PCB associated to zooplankton species are proportional to the carbon concentrations of the corresponding species, which were obtained from the MENOR modelling results reported in Alekseenko et al. (2014, hourly variable open boundary conditions). In order to evaluate the PCB bioaccumulation within the planktonic chain of the GoL due to the Rhone River outflow and local atmospheric deposition, relatively small values (more than 100 times less than in COSTAS and MERLUMED in-situ observations described below) have been chosen at the initial time-step and at the open boundaries.

\section{Available in-situ data}

Several field campaigns data on PCB contamination in the GoL is used in this work. Table 4 resumes measuring periods of two field campaigns in 2011 realised in the COSTAS framework (COSTAS stations, Strady et al, 2015, Tronczynski \& Chiffoleau, 2013) and of six field campaigns in 2004, 2005 and 2006 realised in the RESOMER framework (MERLUMED stations, Harmelin-Vivien et al, 2008). Modeling domain (GoL) with measuring station locations is shown in the Fig. 1. CB153 within two plankton size classes has been measured : 1 . in T200 $(200 \mu \mathrm{m}<\mathrm{X}<500 \mu \mathrm{m})$ - we consider that this will correspond to mesozooplankton (COP) in the model, and 2. in $\mathrm{T} 60(60 \mu \mathrm{m}<\mathrm{X}<200 \mu \mathrm{m})$ - this will correspond to the sum of diatoms and microzooplankton (PHYL and CIL) in the model; and also CB153 within 
TABLE 3: PCB model forcings

\begin{tabular}{|c|c|}
\hline \multicolumn{2}{|l|}{ Rhone River inputs } \\
\hline References and hypotheses & CB153 concentration \\
\hline $\begin{array}{l}\text { ARCMED data for Rhone River; } \\
\text { mean measured value }\end{array}$ & $\begin{array}{l}\mathrm{C}_{S P M}=9 \mathrm{ng} / \mathrm{gC} \\
\mathrm{C}_{D I S S}=34.5 \mathrm{pg} / \mathrm{l}\end{array}$ \\
\hline \multicolumn{2}{|c|}{ atmospheric inputs } \\
\hline References and hypotheses & dry CB153 deposition \\
\hline $\begin{array}{l}\text { Castro-Jimenez et al.(2011) } \\
\text { measurements in Etang de Thau } \\
\text { region }(2007-2008): \\
\sum(18 \mathrm{PCB})=136 \mathrm{ng} / \mathrm{m}^{2} / \mathrm{Y} \\
20 \% \text { of } \sum(18 \mathrm{PCB}) \text { is } \mathrm{CB} 153 ;\end{array}$ & $27.2 \mathrm{ng} / \mathrm{m}^{2} / \mathrm{Y}$ \\
\hline References and hypotheses & wet CB153 deposition \\
\hline $\begin{array}{l}\text { Castro-Jimenez et al. }(2009) \\
\text { measurements in Italy } \\
(2005-2006, \text { monthly mean }): \\
\sum(7 \mathrm{CB})=1.5 \mu \mathrm{g} / \mathrm{m}^{3} \\
21 \% \text { of } \sum(7 \mathrm{CB}) \text { is CB153, } \\
30 \% \text { of CB153 in particulate phase and } \\
70 \% \text { of CB153 in dissolved phase; }\end{array}$ & $\begin{array}{l}P O M_{P C B q}=0.0945 \mu \mathrm{g} / \mathrm{m}^{3} \\
D I S S_{P C B q}=0.2205 \mu \mathrm{g} / \mathrm{m}^{3}\end{array}$ \\
\hline \multicolumn{2}{|c|}{ initial and open boundary conditions (OBC) } \\
\hline Variable & value \\
\hline $\begin{array}{l}\text { dissolved phase }\left(D I S S_{P C B q}\right) \\
\text { mesozooplankton }\left(C O P_{P C B}\right) \\
\text { n\& } \mu \text { zooplankton }\left(C I L_{P C B} \text { and } H N F_{P C B}\right)\end{array}$ & $\begin{array}{l}1 \mathrm{pg} / \mathrm{l} \\
0.25 \mathrm{ng} / \mathrm{gC} \\
0.1 \mathrm{ng} / \mathrm{gC}\end{array}$ \\
\hline
\end{tabular}

suspended solids (SPM).

PCB measurements in plankton were generally performed at the fluorescence maximum encountered in the water column. This maximum was variable according to the stations and varied between 1 and a little more than $20 \mathrm{~m}$. 
TABLE 4: Available in-situ data from field campaigns : C1-C9 stations of the COSTAS field campaign and M1-M4 stations of the MERLUMED field campaign (Harmelin-Vivien et al, 2012, Bodiguel, 2008)

\begin{tabular}{|c|c|c|c|c|c|c|}
\hline Station & Date & $\% \mathrm{C}$ in $\mathrm{T} 200$ & CB153 of T200 (ng/gC) & $\% \mathrm{C}$ in $\mathrm{T} 60$ & CB153 of T60 (ng/gC) & CB153 of MES (ng/gC) \\
\hline \multicolumn{7}{|c|}{ April } \\
\hline M1 & $23 / 04 / 2006$ & 17.13 & 32.52 & 32.45 & 23.30 & \\
\hline M2 & $28 / 04 / 2006$ & 20.13 & 24.99 & 22.96 & 17.90 & \\
\hline M3 & $25 / 04 / 2006$ & 49.67 & 8.68 & 48.00 & 11.69 & \\
\hline M4 & $26 / 04 / 2006$ & 37.26 & 13.58 & 41.20 & 8.01 & \\
\hline $\mathrm{C} 1$ & $15 / 04 / 2011$ & 37.04 & 25.21 & 28.00 & 19.65 & 61.30 \\
\hline $\mathrm{C} 2$ & $16 / 04 / 2011$ & 28.62 & 23.88 & 18.47 & 19.12 & 80.69 \\
\hline C3 & $17 / 04 / 2011$ & 20.62 & 22.11 & 16.43 & 21.51 & 14.98 \\
\hline $\mathrm{C} 4$ & $21 / 04 / 2011$ & 13.21 & 11.99 & 12.43 & 13.15 & \\
\hline C5 & $18 / 04 / 2011$ & 20.62 & 8.12 & 19.98 & 6.71 & \\
\hline C6 & $20 / 04 / 2011$ & 9.41 & 10.36 & 9.19 & 10.07 & \\
\hline $\mathrm{C} 7$ & $20 / 04 / 2011$ & 17.59 & 11.01 & 13.98 & 10.37 & \\
\hline C9 & $21 / 04 / 2011$ & 11.16 & 22.91 & 11.64 & 24.30 & \\
\hline \multicolumn{7}{|c|}{ May } \\
\hline M1 & $15 / 05 / 2004$ & 15.78 & 48.73 & 17.60 & 45.17 & \\
\hline M1 & $14 / 05 / 2005$ & 15.98 & 35.61 & 33.04 & 27.42 & \\
\hline M2 & $14 / 05 / 2004$ & 23.23 & 28.20 & 8.63 & 41.37 & \\
\hline M2 & $16 / 05 / 2005$ & 35.07 & 29.34 & 31.12 & 17.06 & \\
\hline M3 & $12 / 05 / 2004$ & 13.61 & 14.47 & 17.08 & 21.84 & \\
\hline M3 & $10 / 05 / 2005$ & 17.69 & 23.57 & 24.83 & - & \\
\hline M4 & $13 / 05 / 2004$ & 15.28 & 12.30 & 27.00 & 10.56 & \\
\hline \multicolumn{7}{|c|}{ November } \\
\hline M1 & $11 / 11 / 2004$ & 9.62 & 140.33 & 9.60 & 114.58 & \\
\hline M1 & $16 / 11 / 2005$ & 14.80 & 13.78 & 11.63 & 118.23 & \\
\hline M1 & $18 / 11 / 2006$ & 23.04 & 38.85 & 40.20 & 15.72 & \\
\hline M2 & $09 / 11 / 2004$ & 9.48 & 166.98 & 7.02 & 187.04 & \\
\hline M2 & $18 / 11 / 2005$ & 5.51 & 178.58 & 6.42 & 27.26 & \\
\hline M2 & $19 / 11 / 2006$ & 10.37 & 128.16 & 8.79 & 79.98 & \\
\hline M3 & $04 / 11 / 2004$ & 19.68 & 55.34 & 31.50 & 15.94 & \\
\hline M3 & $01 / 11 / 2005$ & 70.88 & 7.53 & 26.40 & & \\
\hline M4 & $08 / 11 / 2004$ & 21.16 & 39.70 & 37.44 & 27.48 & \\
\hline M4 & $14 / 11 / 2005$ & 20.80 & 70.77 & 10.09 & 25.27 & \\
\hline M4 & $20 / 11 / 2006$ & 9.66 & 52.59 & 8.86 & 30.70 & \\
\hline \multicolumn{7}{|c|}{ January } \\
\hline C1 & $23 / 01 / 2011$ & 34.26 & 17.13 & 27.66 & 34.21 & 28.16 \\
\hline $\mathrm{C} 2$ & $24 / 01 / 2011$ & 22.58 & 27.14 & 22.58 & 34.13 & 130.10 \\
\hline C3 & $25 / 01 / 2011$ & 29.96 & 35.35 & 25.16 & 28.90 & 171.34 \\
\hline C5 & $30 / 01 / 2011$ & 33.55 & 11.32 & 28.75 & 11.63 & \\
\hline $\mathrm{C} 9$ & $26 / 01 / 2011$ & 30.60 & 27.64 & 21.06 & 32.26 & \\
\hline
\end{tabular}




\section{Results and Discussion}

\subsection{Comparison with field data}

Model output comparison with the available in-situ data is the first and important step in the PCB transfer modelling. However, we do not claim to have the full coincidence between the model results and measurements, since simplifications and assumptions about the processes and forcings have been considered in the model due to the lack of necessary data : all forcings have a constant CB153 concentration (in the atmosphere and in the Rhone River) associated to carbon; atmospheric deposition have been taken from the different data at different locations of the Mediterranean Sea; wastewater CB153 sources have not been considered in the model. Moreover the available in-situ data is poor for the proper comparison. Therefore model outputs comparison with different data issuing from different field campaigns at two contrasting seasons (in spring and early winter) will help to understand if the developed model is capable to reproduce at least the magnitudes within the same range during the same periods of year.

The measurements were carried out at varying depths between 1 and more than 20m, therefore to simplify, the comparison between spatial CB153 distributions and in situ data is carried out by averaging the model results on the first $20 \mathrm{~m}$ under the sea surface. First, the vertical patterns of concentrations simulated by the model is analyzed in Fig. 4 which shows the vertical distributions of CB153 within T200, T60 and SPM in two contrasting year seasons in the transect of $60 \mathrm{~km}$ from the shore across the longitude $4.451^{\circ} \mathrm{E}$ for the $20^{\text {th }}$ April 2010 and $31^{\text {st }}$ December 2010.

Fig. 4 shows a homogeneity of the values in the surface layer over the first $20-30 \mathrm{~m}$ in the spring and deeper in the winter. This is related to the riverine water intrusion, since the salinity and temperature vertical profiles at these moments present the similar patterns(not shown).

Therefore space distribution of mean over the first $20 \mathrm{~m}$ under the GoL surface for T200, T60 and SPM at two dates in contrasting seasons is compared with the available in-situ data (Fig. 5). All available in-situ data for the same season have been overlayed in the colored circles. Those circles, which have a red boundary correspond to the COSTAS stations. Black bounded circles correspond to the MERLUMED stations.

The contamination level within two size classes of plankton T200 and T60 is in the range $0-40 \mathrm{ng} / \mathrm{gC}$ with the higher concentrations along the coast, especially in vicinity of the Rhone River. From the Fig. 5 we can see that the 
plankton on the western side of GoL shelf (from Roses to Sete shelf zone) is less contaminated $(6-15 \mathrm{ng} / \mathrm{gC})$, than in the eastern side of the GoL shelf (from Sete to Marseille shelf zone), where the contamination is higher (15 $40 \mathrm{ng} / \mathrm{gC}$ ). The orders of magnitude of CB153 associated to suspended solids $(\mathrm{SPM})$ is in the range between $0-180 \mathrm{ng} / \mathrm{gC}$.

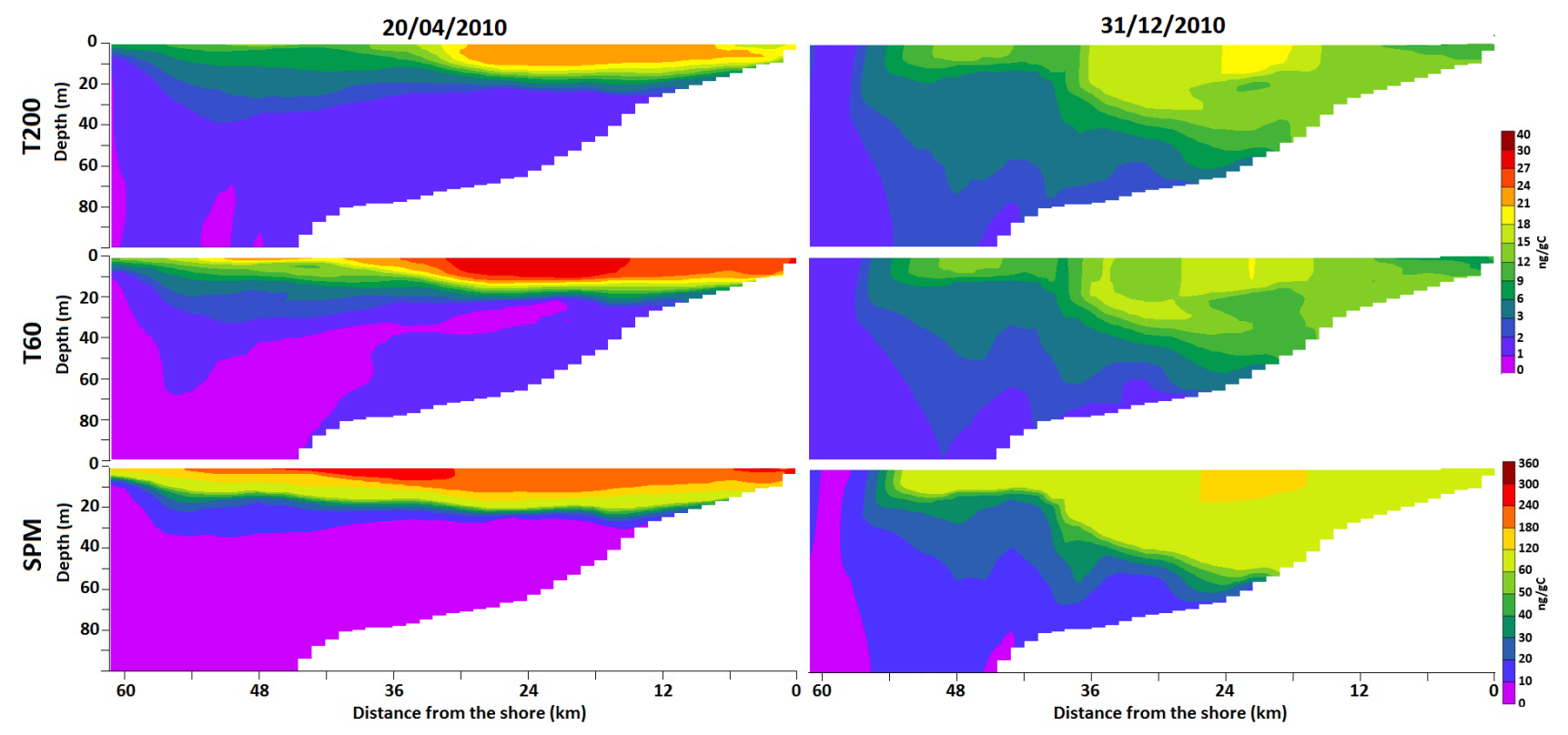

Figure 4: Modeled vertical distribution of CB153 concentrations in the first 100m under the surface in two size classes of plankton T200 (COP), T60 (CIL and PHYL) and in suspended solids in the transect of $60 \mathrm{~km}$ from the shore across the longitude $4.451^{\circ} \mathrm{E}$ for the $20^{\text {th }}$ April 2010 and $31^{\text {st }}$ December 2010.

In general the magnitudes of CB153 concentrations within two size classes of plankton in April are comparable to the measured ones except the eastern station C1. Since we do not take into account any additional sources coming from big cites, such as Marseille, for all compartments the developed model underestimates CB153 concentrations at the eastern GoL station C1 (Fig. 1). The magnitudes of living CB153 concentrations in the end of December are less close to the measured ones in vicinity of the Rhone River.

\subsection{Spatio-temporal CB153 evolution}

In this subsection results on spatial and temporal evolution of living CB153 as well as its annual mean and standard deviations will be reported. 


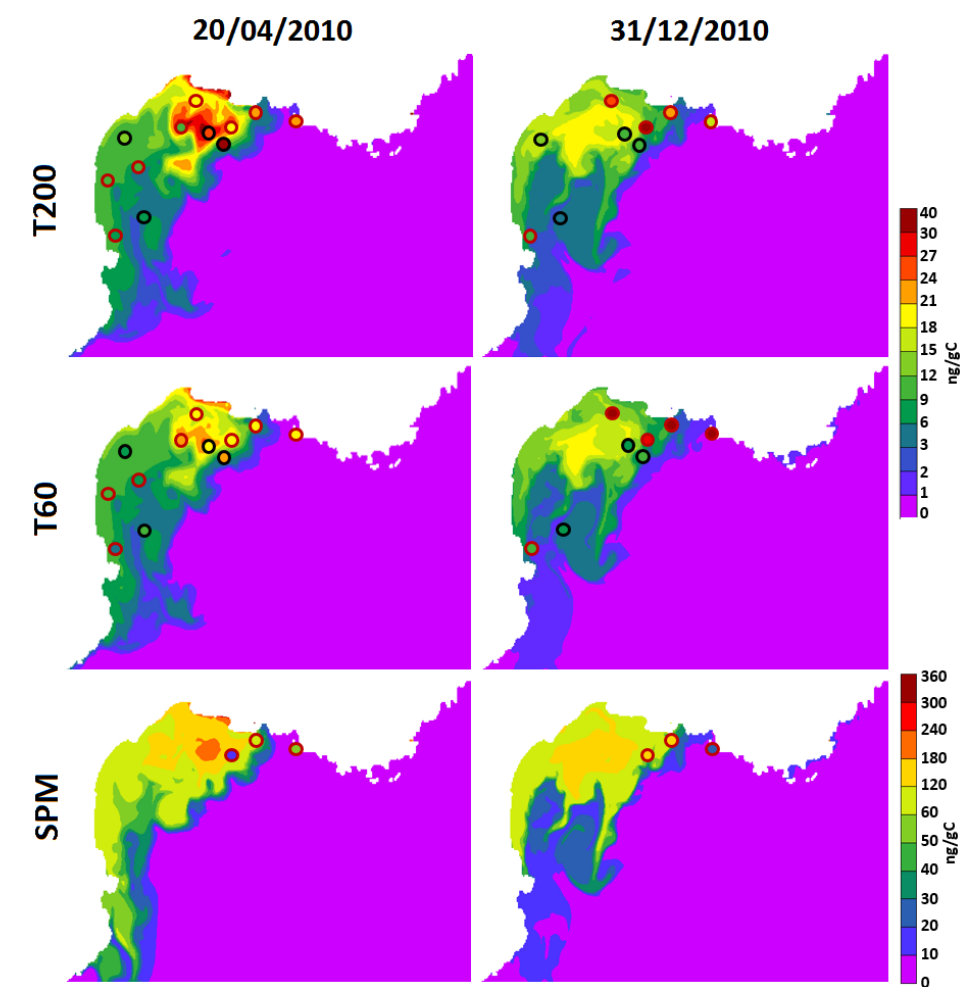

Figure 5: Modeled distribution of CB153 concentrations in two size classes of plankton T200 (COP), T60 (CIL and PHYL) and in suspended solids averaged over 20 meters below the surface for the $20^{\text {th }}$ April 2010 and $31^{\text {st }}$ December 2010. Available in-situ data for the same season is represented by colored circles, where red bounded circles correspond to the COSTAS stations C1-C9, and black bounded circles correspond to the MERLUMED stations M1-M4.

Fig. 6 shows the copepod CB153 concentration distributions at the middle of each month of the year 2010, averaged over 20m depth below the surface. The contamination of copepods varies during the year, with the highest concentrations in the plume Rhone. The months of the year the most contaminated ( $>21 \mathrm{ng} / \mathrm{gC}$ ) during the simulated year are the months of January, July, and December, which correspond to periods following the flooding events of the Rhone River (Fig. 3). During the summer floods have higher impact on copepods. The lowest level of copepods CB153 contamination in the coastal area is obtained in October and November 2010 (below $9 \mathrm{ng} / \mathrm{gC}$ ). The offshore zone is less contaminated during the modeled year, but this result is strongly linked to the choice of concentrations at the open 
boundaries of the GoL. The concentration of CB153 in copepods arriving from outside of the modeled area was chosen arbitrarily low $(0.25 \mathrm{ng} / \mathrm{gC})$.

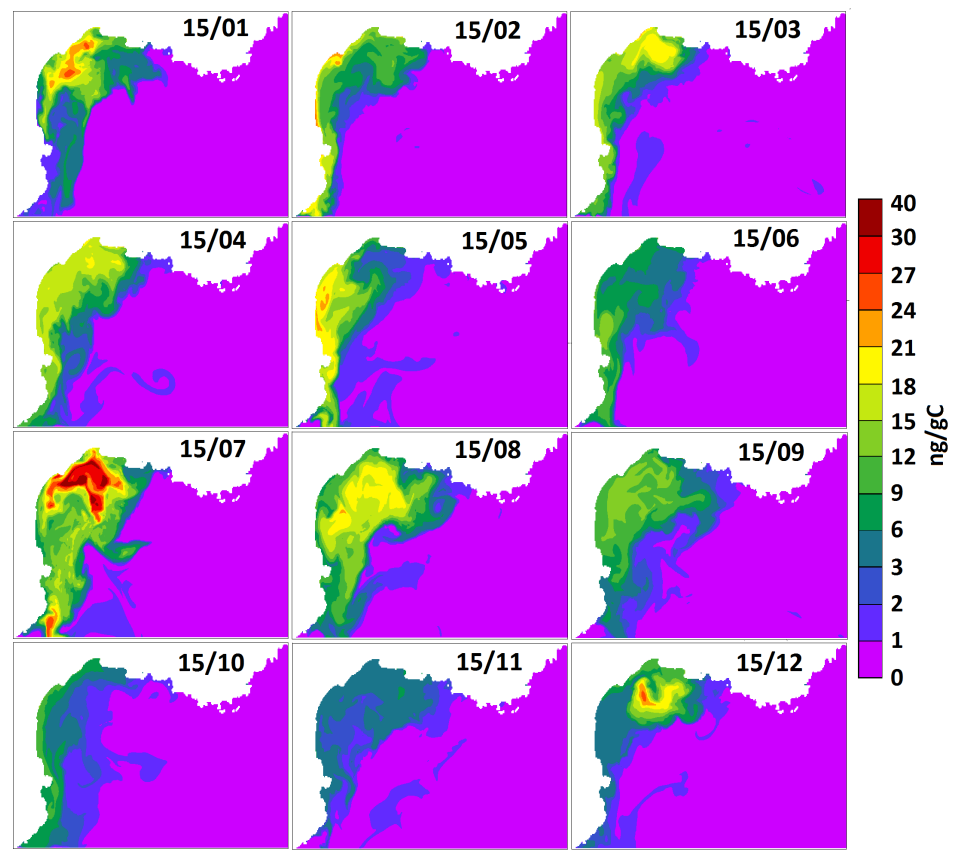

FigURE 6: Instant copepod's CB153 concentration (ng/gC) evolution for the period of the year 2010; average over $20 \mathrm{~m}$ under the sea surface.

Three areas of GoL with different water depth ranges have been selected in order to analyze seasonal variations in stocks and concentrations of CB153 associated to plankton (Fig. 1) :

- offshore deep GoL zone with the depth $600 \mathrm{~m}<\mathrm{H}<2000 \mathrm{~m}$ and volume $V_{1}=1.59 * 10^{13} \mathrm{~m}^{3}$;

- intermediate shelf GoL zone with the depth $50 \mathrm{~m}<\mathrm{H}<600 \mathrm{~m}$ and volume $V_{2}=3.03 * 10^{12} \mathrm{~m}^{3}$;

- coastal zone with the depth $0 \mathrm{~m}<\mathrm{H}<50 \mathrm{~m}$ and volume $V_{3}=7.39 *$ $10^{10} \mathrm{~m}^{3}$.

CB153 stocks and concentrations associated to three groups of plankton, such as lower trophic levels (bacteria and phytoplankton), small zooplankton (micro and nanozooplankton), and the higher trophic level (copepods) for three selected zones have been investigated (Fig. 7). CB153 stocks show the level of contamination for each zone, whereas concentrations show the contamination level per carbon biomass of the corresponding plankton group 
presented in the volume of corresponding zone. CB153 stocks and concentrations were calculated in the entire volume of each zone, therefore the contamination level will be lower than in the previous figures with a spatial distribution due to the vertical integration. Such an integration thus dilutes the values in deeper zones. Anyway it should be noted from our previous results that for all zones the maximum concentrations is located rather in the surface layers (Fig. 4).

The CB153 stock of the intermediate zone $(50 \mathrm{~m}<\mathrm{H}<600 \mathrm{~m})$ reaches about $0.3 \mathrm{~kg}$ associated to bacteria and phytoplankton in May 2010, about $0.2 \mathrm{~kg}$ in small zooplankton in August 2010 and about $0.1 \mathrm{~kg}$ in copepods in August 2010 also.

In the offshore zone $(600 \mathrm{~m}<\mathrm{H}<2000 \mathrm{~m})$ living CB153 stock is mostly accumulated by small zooplankton, whereas in two shallower zones it is mostly accumulated by bacteria and phytoplankton.

In all three zones CB153 concentration is raising in January and in July 2010, what is happen after two Rhone River flood events (Fig. 3) started in the middle of December 2009 and in the middle of June 2010.

The highest CB153 concentrations within three plankton groups is in the coastal zone $(0 \mathrm{~m}<\mathrm{H}<50 \mathrm{~m})$, where it reaches $20 \mathrm{ng} / \mathrm{gC}$ in the middle of January and $16 \mathrm{ng} / \mathrm{gC}$ in the middle of July. There are also two additional peaks of the concentration in the coastal zone - in March and April (corresponding to approximately $15 \mathrm{ng} / \mathrm{gC}$ and $13 \mathrm{ng} / \mathrm{gC}$ ). These two spring peaks of CB153 concentration are correlated to the CB153 stock increase, especially in smaller organisms, such as bacteria and phytoplankton and smaller zooplankton due to the interaction of two effects : spring bloom and small Rhone River runoff increase (see Fig.8a). In the intermediate zone the concentration reaches 10 $\mathrm{ng} / \mathrm{gC}$ for bacteria and phytoplankton and $5 \mathrm{ng} / \mathrm{gC}$ for copepods in the end of January - beginning of February. In the deep offshore zone concentrations are close within three groups and fluctuating around $1 \mathrm{ng} / \mathrm{gC}$, except in the July and August. Bacteria and phytoplankton have higher concentrations after the Rhone River flood events. However the open boundary influence becomes to be non-negligible in the deep offshore zone : such a concentration level of $1 \mathrm{ng} / \mathrm{gC}$ is four times more than the contamination level of copepods coming from the open boundary, and ten times more than the contamination level of micro- and nanozooplankton. 

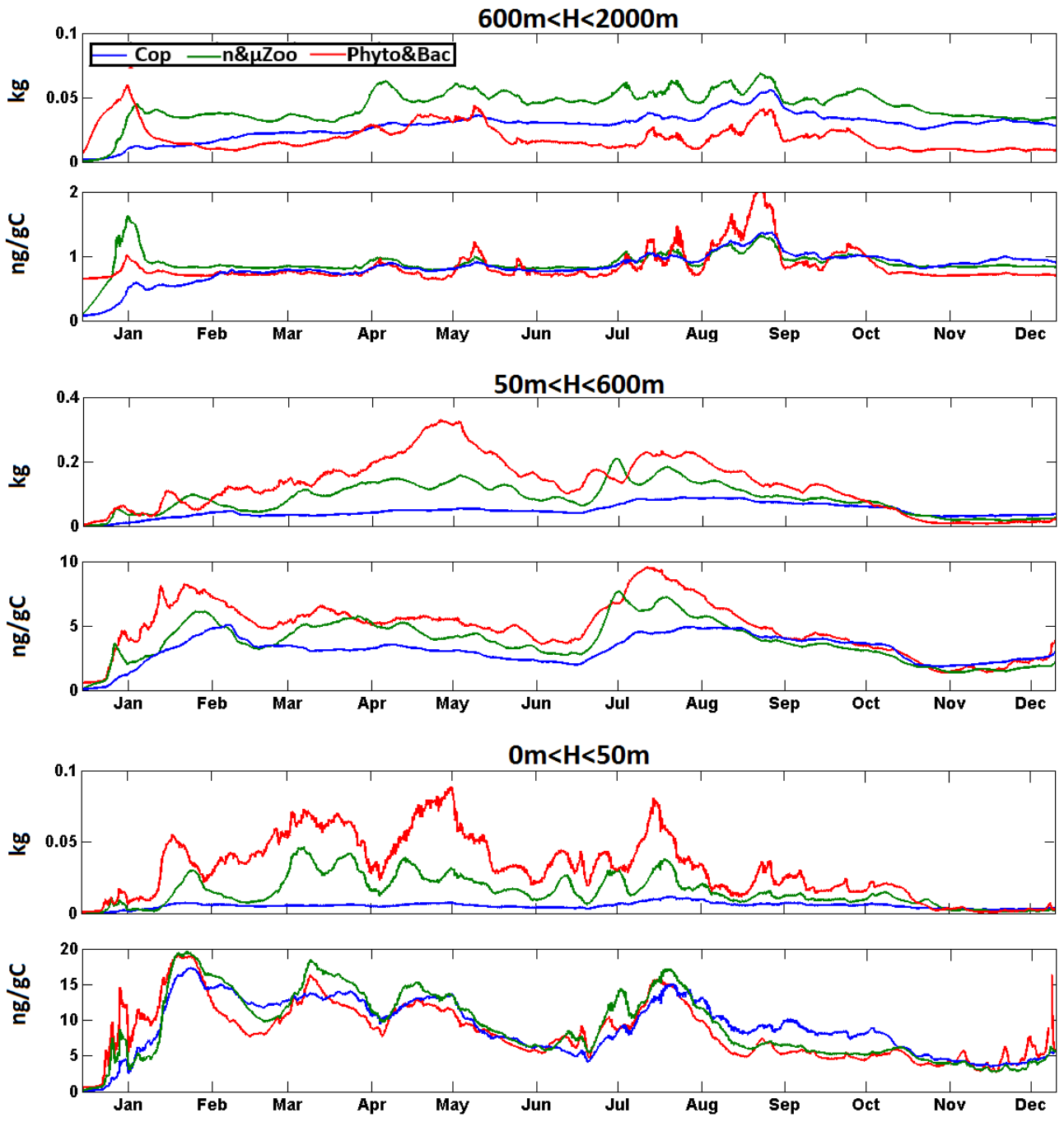

Figure 7: Living CB153 evolution in terms of stock $(\mathrm{kg})$ and concentration $(\mathrm{ng} / \mathrm{gC})$ for three different zones of GoL.

\subsection{CB153 fluxes}

In this subsection we advance in understanding the contamination pathways, i.e. which biogeochemical processes are more important in organisms contamination and which organisms are more impacted by these processes in the contrasting locations of GoL (inshore/offshore). The analysis of seasonal variations of CB153 fluxes and stocks in the GoL zone $\mathrm{H}<2000 \mathrm{~m}$ (including 
coastal, intermediate and offshore zones) and then in each zone separately are reported.

Figs. 8a-c show the annual variation of main contamination cumulated fluxes and stocks of living CB153 and carbon. Among these fluxes are the dominant forcings (Fig. 8a) such as the Rhone River outflows, atmosphere deposition and open boundary condition outflow (slope $>0$ - gains, slope $<0$ - loses). From the Fig. 8a it is seen that almost all the CB153 issuing with the Rhone River and by the atmosphere is transported by the currents away from the zone (negative OBC exchange). At the scale of the chosen zone $(\mathrm{H}<2000 \mathrm{~m})$ the Rhone River outflow seems to be the most impacting forcing bringing about $40 \mathrm{~kg}$ of CB153 during the simulated year. About $10 \mathrm{~kg}$ of CB153 came to water from the atmosphere. Almost all CB153 is in dissolved phase, which stock is varying from about $58 \mathrm{~kg}$ to about $70 \mathrm{~kg}$ after the Rhone flood events.

CB153 arrives by the Rhone in rather particulate form (small peaks in December and June) and it desorbs at sea and supplies the dissolved stock (increase of the dissolved stock after that of the particulate stock, but dissolved CB153 peaks are smoother and spread out in time). Then a very small part of the total CB153 is adsorbed into the living matter (stocks of the order of 0.1 to $0.45 \mathrm{~kg}$ (Fig. 8b) compared to the dissolved CB stock (Fig. 8a) of the order of $60 \mathrm{~kg}$.

Fig. 8b-c show living CB153 and the corresponding carbon stock repartition and seasonal variation within modeled organisms. It is seen that the dynamics of CB153 and of carbon biomass is not similar; so the ratio between the living CB153 and carbon is changing for all organisms during the simulated period. For example, PHYL carbon biomass stock is low (below $1 \mathrm{~kg}$ ) from the beginning of the simulation until the beginning of February 2010, whereas its CB153 stock is higher (up to $0.1 \mathrm{~kg}$ ) between January and February (just after the flood event), comparing to other year periods. Then the carbon biomass stock of PHYL is increasing due to the phytoplankton's spring bloom and this new biomass has decreasing contamination level.

Fig. 9 resumes CB153 repartition at two different dates (15/04/2010 and $15 / 07 / 2010)$ for three zones described in the previous subsection. Such a figure show that about 40 - $60 \%$ of living CB153 stock is adsorbed by bacteria for two dates in the coastal and intermediate zones. In the offshore zone $(600 \mathrm{~m}<\mathrm{H}<2000 \mathrm{~m})$ the CB153 stock contains more bacterial CB153 in the spring and in the summer - more CB153 accumulated by zooplankton.

Annual gains and loses of CB153 are presented per zone in Fig. 10. 

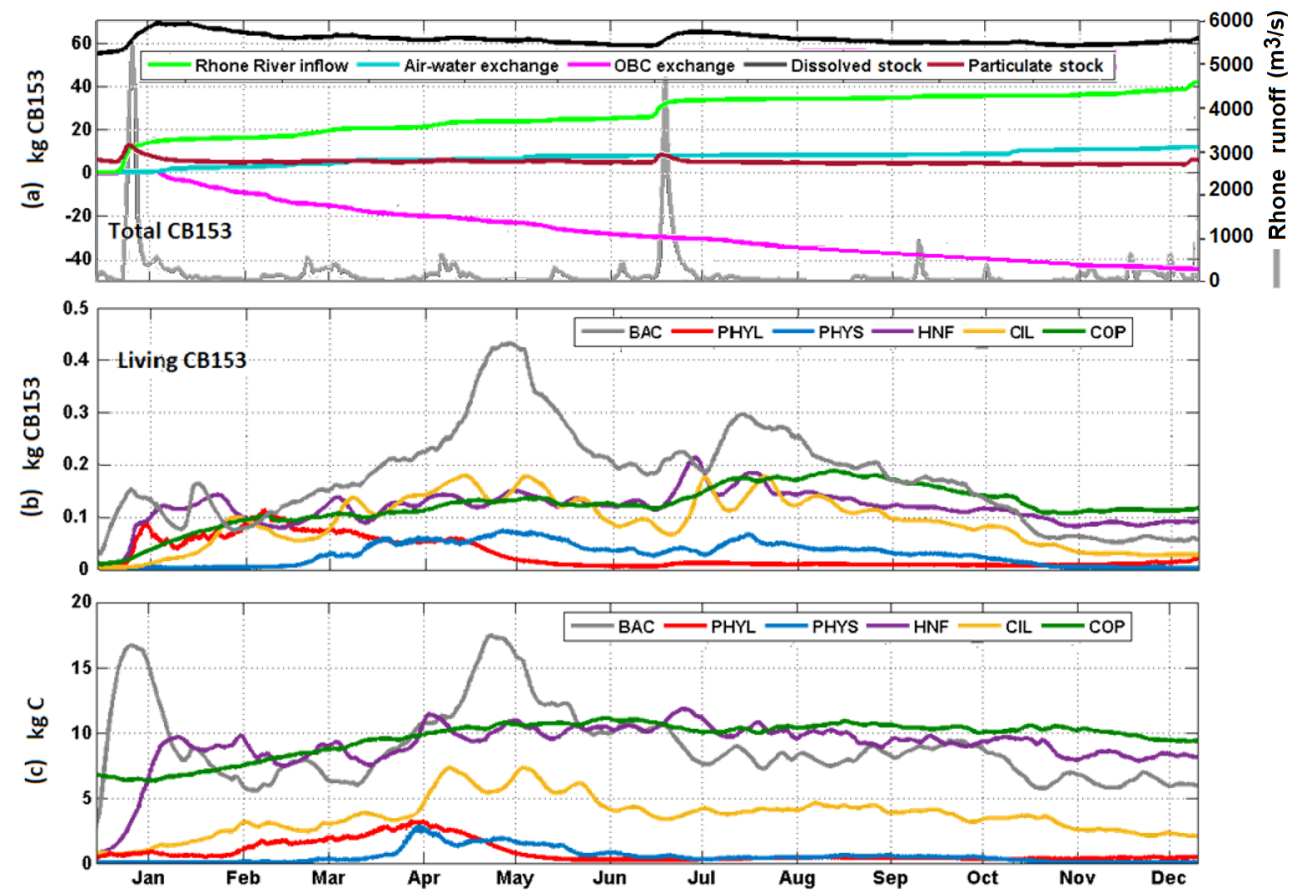

Figure 8: Time evolution in the GoL $(\mathrm{H}<2000 \mathrm{~m})$ of (a) CB153 cumulated process fluxes, dissolved CB153 stock, particulate CB153 stock (kg), and Rhone River runoff $\left(\mathrm{m}^{3} / \mathrm{s}\right),(\mathrm{b})$ living CB53 stocks $(\mathrm{kg})$, and (c) living carbon stocks $(\mathrm{kg})$.

Fig. 10a show gains (positive values) and loses (negative values) of total CB153. The total stock of the coastal zone is mainly increased due to the Rhone River loads, however almost all gains flew away from this zone to the intermediate zone $(50 \mathrm{~m}<\mathrm{H}<600 \mathrm{~m})$. Therefore, the intermediate zone $(50 \mathrm{~m}<\mathrm{H}<600 \mathrm{~m})$ has more $\mathrm{CB} 153$ gains than loses during the simulated year. Comparing to the coastal zone where the Rhone River is found to be the main contamination pathway, in two offshore zones $(50 \mathrm{~m}<\mathrm{H}<600 \mathrm{~m}$ and $600 \mathrm{~m}<\mathrm{H}<2000 \mathrm{~m}$ ) atmospheric deposition is the major contamination pathway. Comparing to other zones in the deepest offshore zone volatilisation process become to be considerable. The gains of total CB153 in the intermediate zone during the year is mostly in the non living form (dissolved and particulate), since the living matter CB153 fluxes are self compensating (sum of gains and loses is close to zero, see Fig. 10c).

Fig. 10b show gains and loses of living CB153 - cumulated processes fluxes 


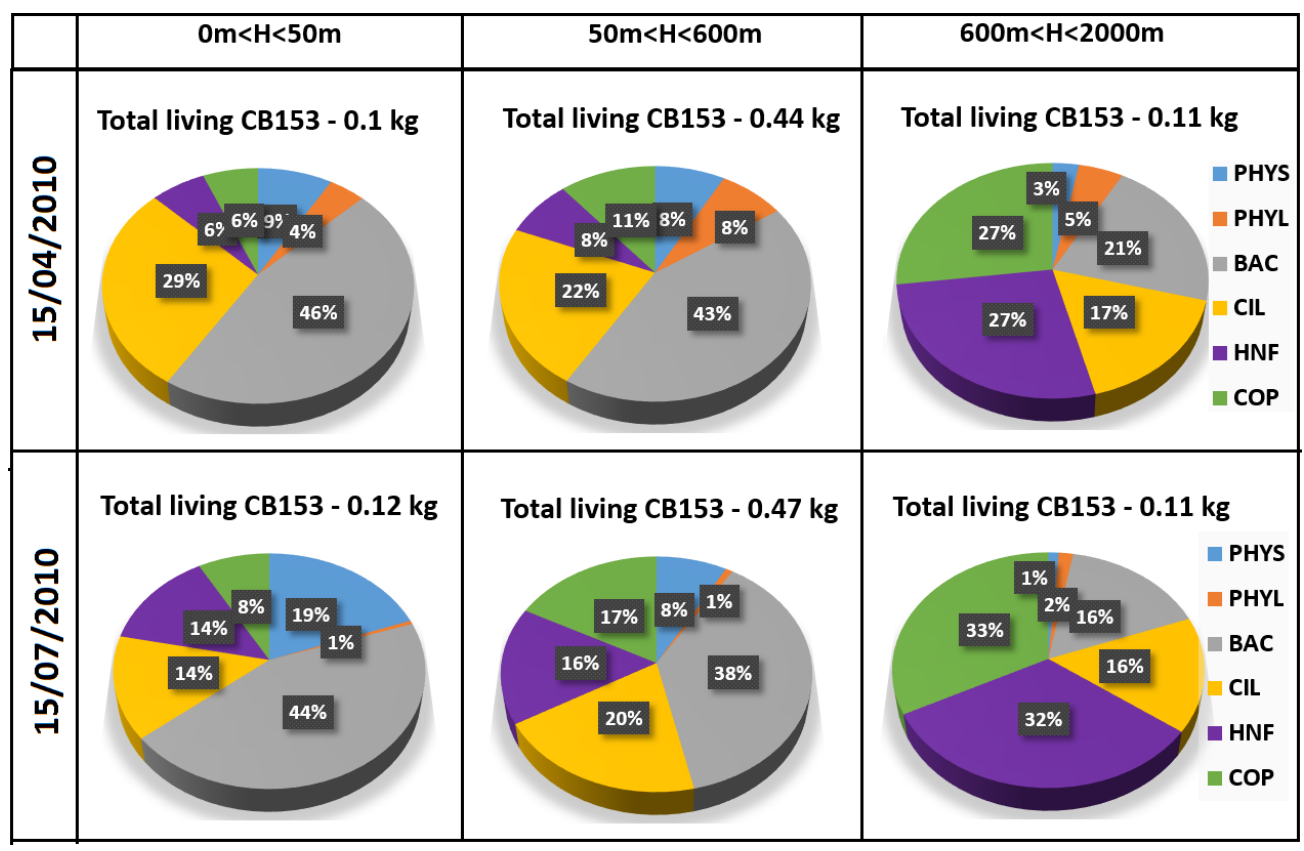

FIGURE 9: Living CB153 repartition in 3 zones of GoL 15/04/2010 and 15/07/2010

at the end of the simulated year. In three zones after one year approximately a major part of the adsorbed CB153 by living matter was transformed into POM and DOM due to mortality. Another part was transformed to POM and DOM due to excretion or left the boundaries of the corresponding zone. The process of grazing is not visible in this figure since the matter fluxes between preys and predators due to the grazing are self compensating (see Fig. 11a).

Copepod CB153 annual stock gains and loses have been summarized in the Fig. 10c. The most important part of the CB153 came by the grazing, whereas the adsorbed part of CB153 is very low. All copepod CB153 gains are transformed into particulate and dissolved non-living matter due to mortality and excretion or left the corresponding zone.

Fig. 11 show more precisely biogeochemical process repartition for modeled organisms per zone. In all zones among the organisms bacteria adsorbs more CB153 and copepod adsorbs less CB153, such a tendency increases from shallower to deeper zone. In the deeper zone HNF obtain more CB153 from bacteria through grazing. In turn, in the intermediate zone copepod's grazed CB153 is more dominant among other predators. Higher CB153 mor- 


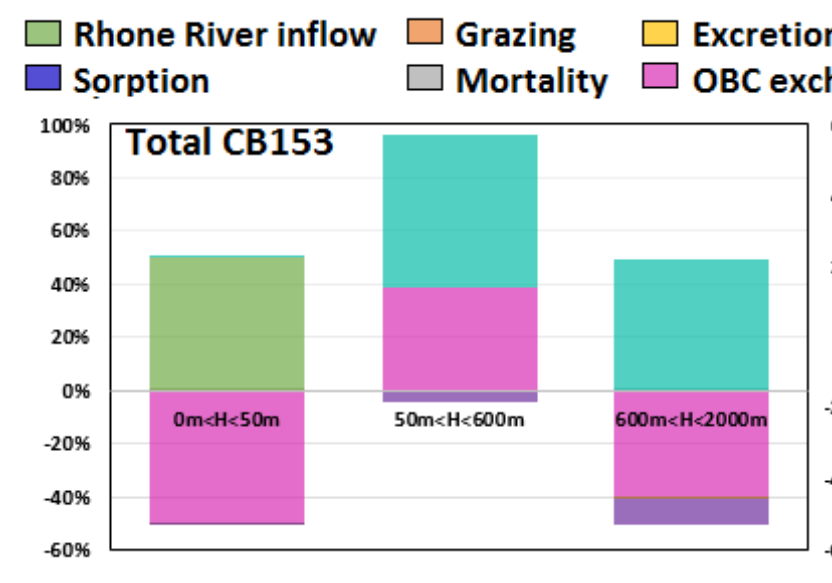

(a)
Air-water exchange $\square$ Mineralization Volatilization

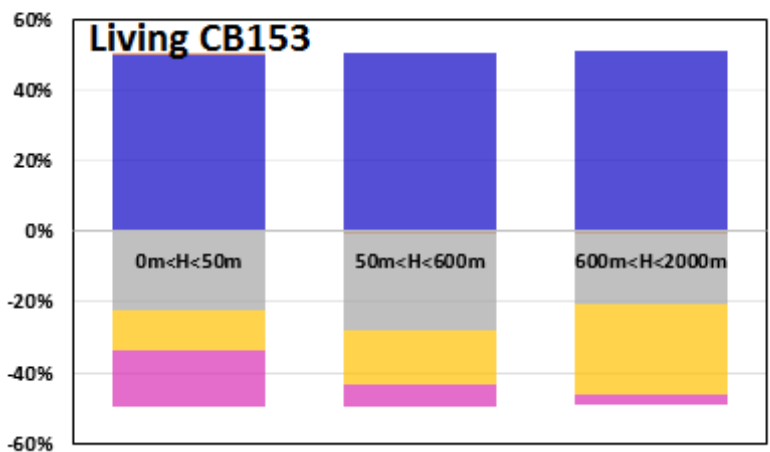

(b)

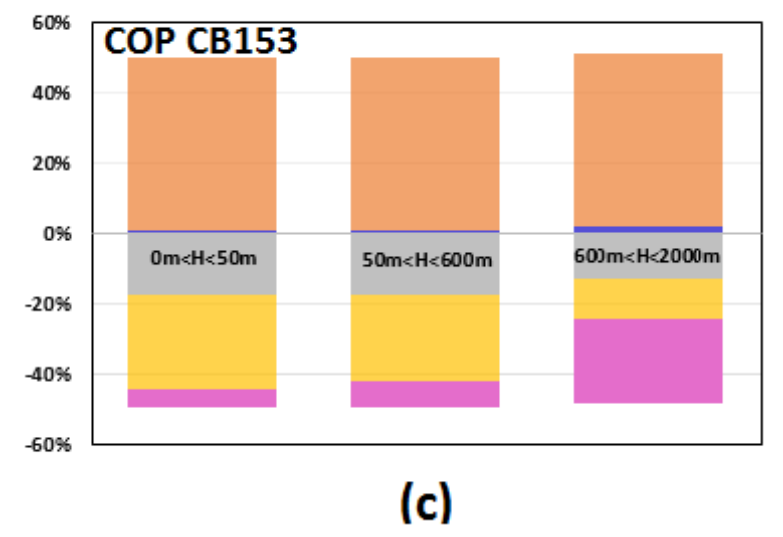

Figure 10: Total CB153 cumulated process fluxes repartition in 3 zones at the end of the year

tality flux associated to bacteria is found in the shallower zone $(0 \mathrm{~m}<\mathrm{H}<50 \mathrm{~m})$. HNF have the highest excretion flux in this zone since this flux also contains a mortality flux.

To summarize these results, annual CB153 fluxes and difference of CB153 stocks between the end and the beginning of the year are shown schematically on Fig. 12 for the zone of $\mathrm{H}<2000 \mathrm{~m}$, which unites all three studied zones. In this figure organisms have been united on the three groups : PHY\&BAC (phytoplankton and bacteria), $\mu \& n Z O O$ (micro- and nanozooplankton, i.e. HNF and ciliates) and mesoZOO (mesozooplankton, i.e. copepods). Red numbers with signs inside each group are the stocks differences (positive numbers mean 


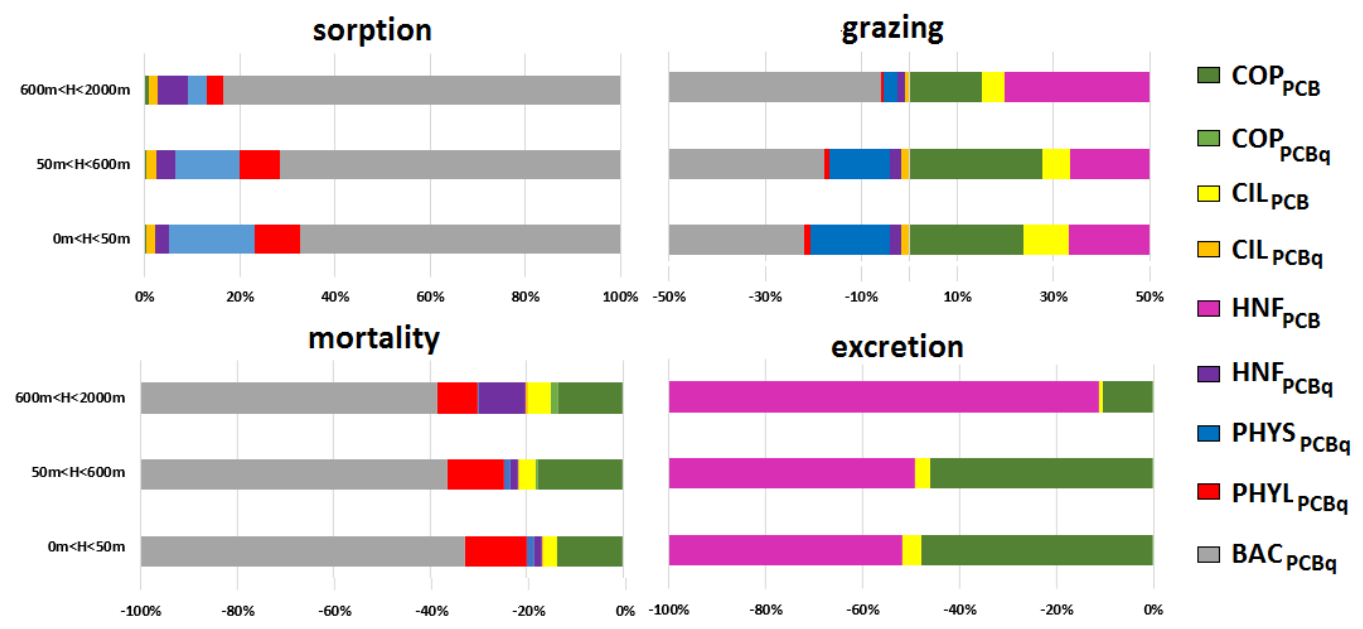

FIGURE 11: Living CB153 cumulated process repartition in 3 zones at the end of the year

CB153 stock accumulation after 1 year, while negative - stock decrease).

For each group we found CB153 stock accumulation after the simulated year (Fig. 12). The major part of the accumulated CB135 stock is in the dissolved form of the order of $33 \mathrm{~kg}$ increase. Such an accumulation in the dissolved form is related to the mineralization of CB153 associated to particulate matter issuing from The Rhone River. Rhone River is the main source of CB153 : mainly in non-living particulate form. A part of particulate non-living CB153 is desorbed into dissolved form and adsorbed to organisms (specially phytoplankton and bacteria) and the rest of non-living particulate CB153 turned into dissolved form through mineralization. CB153 adsorbed to phytoplankton and bacteria was transferred to the higher trophic levels through grazing fluxes and then recycled by all organisms into a non-living form through mortality and excretion fluxes. Only small part of CB153 is accumulated by the organisms during this simulated year : about $1 \mathrm{~kg}$ of living CB153 stock have been increased at the end of year.

\subsection{Sorption parameters impact}

It is assumed in the model, that the sorption of PCBs by bacterio planktonic populations is a rapid sharing process. Sorption coefficients are estimated using the various field data, however this data often is not very precise : the phytoplanktonic and zooplanktonic populations and detrital matter are not always differentiated in samples, the dissolved matter composition contai- 


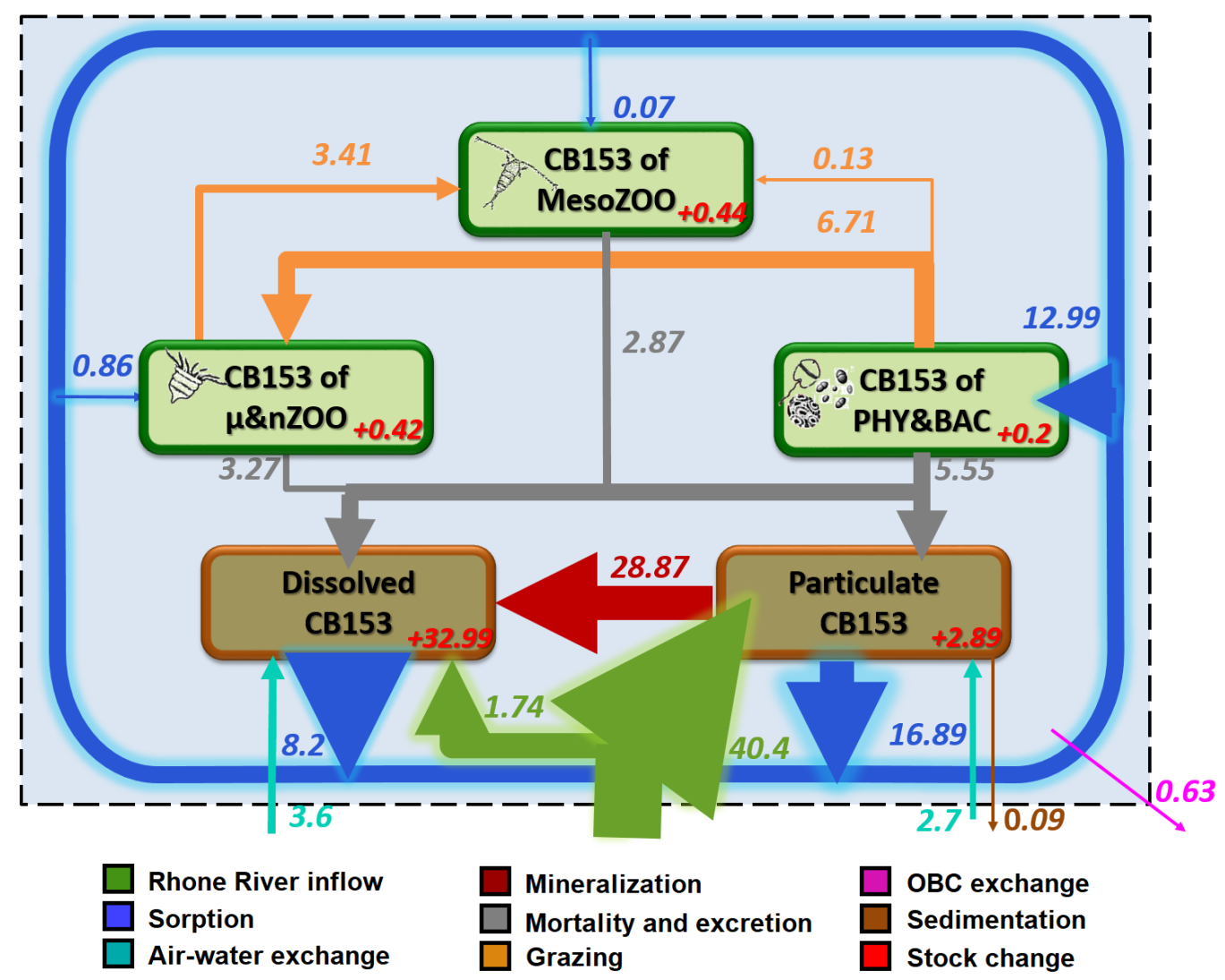

Figure 12: CB153 fluxes $(\mathrm{kg} / \mathrm{Y})$ and stocks $(\mathrm{kg})$ difference between the beginning of simulation and at the end of the year in 3 zones.

ning hydrophobic organic contaminants remains uncertain. In the reference simulation, the sorption coefficients (Koc) are derived from the literature (see Table 1). Few information is found in the literature about the sorption coefficients for organisms of separate functional groups. According to measurements performed by Walberg et al. (1997) Log10(Koc) for CB153 is varying with the size of organisms (excluding mesozooplankton) : from 6.5 for organism size of $0.2-2 \mu \mathrm{m}$ to 5.7 for organism size of $>10 \mu \mathrm{m}$. Nizzetto et al (2012) showed experimental results for the bioconcentration factor of phytoplankton and bioamplification factor of zooplankton, which related with the sorption coefficient. These results show a strong variability (with a difference of about one log unit) depending on the period of algal bloom : pre-bloom, bloom and post-bloom periods. In the present model it is assumed a strong 
TABLE 5: Sorption scenarios.

\begin{tabular}{|l|l|l|l|l|l|}
\hline & sc. ref. & sc.1 & sc.2 & sc.3 & sc.4 \\
\hline Log10 $\left(\mathrm{Koc}^{Z O O}\right)(\mathrm{ml} / \mathrm{g})$ & 5 & 4.5 & 5.5 & 5 & 5 \\
Kinetic desorption rate of SPM $\left(d^{-1}\right)$ & 4 & 4 & 4 & 1 & 8 \\
\hline
\end{tabular}

coefficient for phytoplankton and bacteria $(\log 10(\mathrm{Koc})=6)$ and a lower coefficient for nano-, micro- and mesozooplankton $(\log 10(\mathrm{Koc})=5)$. When Koc of organism is increased by one log unit, the transfer flux due to sorption is multiplied by 10 . Therefore, PCB transfer flows simulated by the model should be sensitive to the sorption coefficients used.

Another basic assumption in the model is that for the PCBs associated to the suspended matter coming from the Rhone River the sorption process is not instant and has a kinetic rate $(4 / d)$. The duration of the desorption process is related to the time required for the diffusion of the contaminant through the solid matrix and this process is surely time-variable in reality. But there is no certain information about this coefficient in the literature. Therefore it is considered constant in the model. Its value have been chosen due to the better model result agreement with a few available field data.

Four additional scenarios have been performed to analyze the impact of uncertain sorption parameters. All scenarios are summarized in the Table 5. Two additional annual simulations have been performed with two different values for zooplankton sorption coefficient : $\log 10(\mathrm{Koc})=4.5$ and 5.5. Another two annual simulations with two different desorption kinetic rates $(1 / \mathrm{d}$ and 8/d) of CB153 associated to the suspended particles (SPM) have been performed.

The CB153 stock difference between these scenarios and the reference scenario (in \%) have been computed for all variable, however only the most sensible variables have been presented on the Fig. 13.

Fig. 13a show that model outputs are sensible to the sorption coefficient increase : Koc increase lead up to $38 \%$ higher stocks of CB153 cumulated by copepods (in January) and up to $30 \%$ - by smaller zooplankton (in December). Koc decrease lead up to $12 \%$ stock decrease in copepods (in January and December). Such zooplankton sorption coefficient change do not have an important impact on the phytoplankton and bacteria (Fig. 13c) - the differences between stocks are quite low (below 10\%). 
The SPM desorption kinetic rate increase/decrease lead to the increase/decrease of CB153 stock associated to SPM (Fig. 13b), what imbalance all stocks.

The highest changes are observed in SPM, copepod and small zooplankton stocks when the kinetics rate became 4 times less than in the reference scenario. Therefore due to this decrease of contaminant desorption from SPM coming from the Rhone River, CB153 stayed longer time in the non living particulate phase. Moreover in the biogeochemical model it is hypothesized that the SPM particles and ciliates are two main food sources for juvenile copepods (Alekseenko et al, 2014). Thus the increased CB153 SPM stock were grazed directly by juvenile copepods. The other CB153 pools obtained less available CB153 stock to adsorb, so their CB13 stocks decreased.

When the desorption have been accelerated (scenario 4), the CB153 coming in the particulate phase from the Rhone River become to be adsorbed rapidly by all organisms. So in this case their CB153 stocks have been increased.

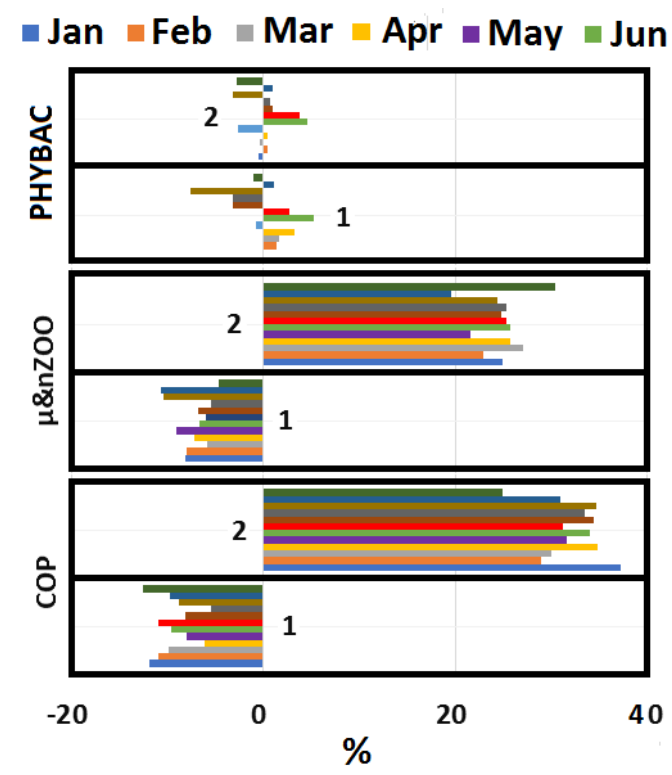

(a)

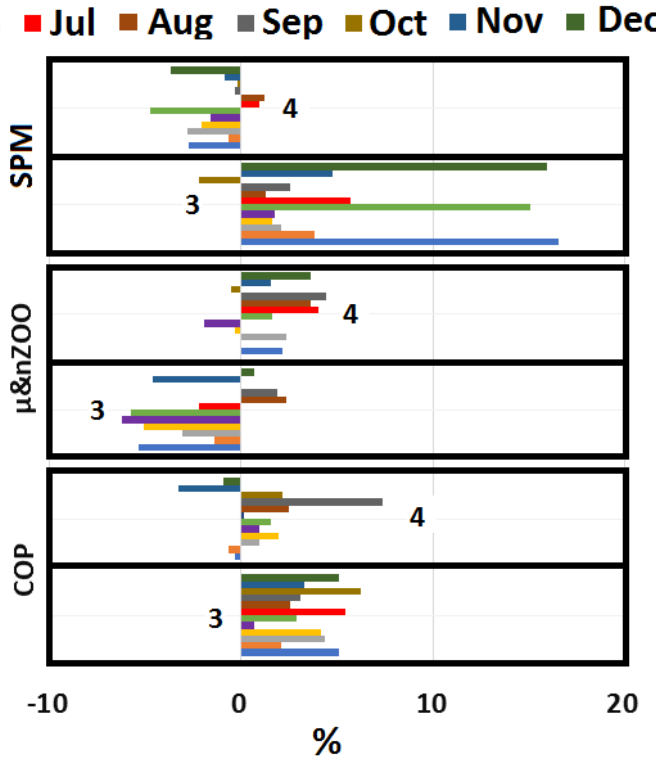

(b)

Figure 13: Scenarios on (a) Koc change of zooplankton (scenarios 1 and 2) and (b) on non-living particulate organic matter (POC) kinetic sorption rate change (scenarios 3 and 4). Monthly mean CB153 stock difference relative to the reference scenario in the zone $0<\mathrm{H}<2000 \mathrm{~m}$ of GoL. Only mostly impacted variables are shown. 


\subsection{Discussion}

The first objective of the MARS3D model was to simulate the spatial and temporal dispersion of PCBs in the Gulf of Lion, their concentrations linked to the inputs and their offshore sources, sediment or atmospheric. Indeed, even if the contaminant is present in Mediterranean water in the form of several species (free, dissolved or linked to living and non living particulate matter), the dominant processes that determine the distribution of concentrations and stocks in the Gulf of Lion are the coastal contributions and the transport related to the hydrodynamics.

The MARS3D model has shown its validity to reproduce the transport and mixing of water masses in the western Mediterranean; it is therefore an effective tool to describe the evolution of concentrations of contaminants, which depend on the forcing during the simulated year. But the model encounters several limits : these calculated concentrations also depend, to a greater or lesser extent, on the assumptions chosen to quantify the inputs, to reproduce the particles settling and to define the boundary concentrations.

Thus, although the Rhone River runoff and the associated discharges of organic matter are well known through frequent measurements, and although the order of magnitude of the CB153 contamination flow is fairly well understood thanks to measurements carried out on an annual cycle (Tronczynski et al, 2012), it is often imprecise for periods of large floods. As a first approach the CB153 concentration in dissolved and particulate phases were taken constantly proportional to the Rhone discharges and carbon of suspended solids.

The contributions of the coastal cities are not taken into account in the model, the flows being considered much lower than those of the Rhone River. However, contaminant concentrations can be quite high in discharges of wastewater or small rivers and can generate dispersal plumes in the neighboring coastal regions that are quite remarkable during periods of flood (see study in Marseille in Pinazo et al., 2013). Therefore for this reason model always underestimates CB153 concentrations in the C1 station measured in the Marseilles waters.

For a hydrophobic congener such as CB153, the dispersion of the turbid plume and the behavior of the particles during their transit in the GoL play an important role in the residence time of the particles in the water column. The sedimentary model used here is rudimentary (no sand, no waves, low settlement velocities for the detrital material as a whole, neglecting of the rapid settlement of some heavier particles). As a result, most of the particles 
from the Rhone River remain in the water column, while several studies have shown that a significant part is deposited in the pro delta (during flood events, Dufois et al., 2008).

Although total suspended solids are measured regularly, characterization of the material is still poorly explored. PCBs are associated with fine and organic sediments (Karickhoff et al., 1979), but what are the rates of settlement of this material? Can it be represented by a single particulate stock having a homogeneous average behavior or several fractions of particulate material with different rates of settlement, different carbon contents and different sorption coefficients should be considered? Differentiating the types of organic matter according to their origin would lead to an huge increase in the number of variables transported in the model, without having enough knowledge about the parameters to associate them.

Although CB153 is a hydrophobic contaminant, more attracted to particles than dissolved phase, it is present in Mediterranean waters mainly in dissolved form, since turbidity is very low. Thus the dissolved and particulate concentrations of CB153 are sensitive to the partition coefficient Koc only in the near field of river plumes.

The uncertainties and inaccuracies linked to the assumptions on inputs and particles transport can not be evaluated by lack of measurements and it is mainly the patterns and the orders of magnitude of the concentrations that are retained.

The second objective of the model MARS3D/Eco3M/PCB application was to study the role of plankton in the PCB transfer to high trophic levels. The model MARS3D/Eco3M satisfactorily simulates the spatial and temporal change in nutrients, organic matter and plankton (Alekseenko et al., 2014). By adding variables and processes describing the behavior of CB153 species, the model simulates PCB transfers associated with trophic relationships between different functional groups.

One of the first difficulties is that the proportion of CB153 transferred to living matter is very low (less than 1\%); the strong uncertainties on the quantities of pollutants discharged in the environment are therefore reflected in the very low levels of contamination in the first links of the trophic chain, which in addition can not be adequately verified because of the difficulties of observation. These low concentrations are nevertheless the basis of transfer and accumulation towards the highest links of the food chain, where toxic levels may be reached by bioaccumulation.

The PCB speciation and transfer processes are taken into account in the 
model MARS3D/Eco3M/PCB based on classical concepts and simple a priori assumptions : mainly the transfer of PCBs between the various compartments and species are proportional to carbon transfers, which are themselves related to biogeochemical processes and the process of adsorption/desorption of PCB is considered as a rapid sharing process. Koc values were derived from the literature (see Table 1), assuming a strong coefficient for phytoplankton and bacteria and a lower coefficient for zooplankton.

The results of the model show quasi-equivalent concentrations in different plankton species, with greater temporal and spatial variability in the coastal region as a function of inputs and seasons. Average concentrations, calculated over the whole water column and over large areas, are much more stable offshore, although contamination related to river intakes is still visible, especially on the first links (bacteria and phytoplankton).

This is also generally true for stocks that show some different variations due to seasonal biogeochemical cycles of the species themselves. Throughout the area impacted by the Rhone plume to the edge of the plateau, stocks of PCBs linked to bacteria and phytoplankton are larger than those associated with zoooplankton, whereas it is the opposite in the open sea. There was also an increase in stocks during the simulated year, particularly in the spring and summer and a return to lower values in the fall.

These same behaviors are found even if the desorption kinetics or the partition coefficients for the mesozooplankton are varied. However, the model always uses constant coefficients throughout the year, but in-situ measurements shown that the sorption coefficients can vary according with seasons (Sobek et al. ,2004) and is not only proportional to Kow. Unfortunately; there are too few measurements to introduce and analyze this behaviour in this work.

The relatively homogeneous concentrations of all the planktonic species (bacteria, phyto, nano, micro and mesozooplankton) as observed in the measurements and as shown by the model lead us to the conclusion that these planktonic compartments play only a role of transfer of contaminant to the highest links but without the accumulation of PCBs. Of course the model does not take into account processes that could introduce a greater retention of the contaminant compared to the carbon, for example an excretion efficiency. These processes have been observed on small pelagic fish or other larger predators (Campens and Mackay 1997, Borga and Di Gurado, 2005), but it is probably very low in zooplankton.

Almost all results from this work are shown here by averaging concentra- 
tions, stocks and transfer fluxes over three fairly large areas characterizing the coastal area, the plateau and the offshore area. It is a simpler and more comprehensive way of analyzing the results for the contaminant, for which there is too little detailed information in time and space. The interest of the 3D model for the simulation of CB153 is therefore not really exploited here and the complexity of the model also prevents real sensitivity studies on the processes that affect the distribution of the PCB. The three-dimensional nature of the dynamics of the water masses and associated biogeochemical processes is no longer to be demonstrated and the interest of the 3D model is therefore obvious, especially to simulate the spatial and temporal distribution of an anthropogenic contaminant. However, it is a difficulty to study more precisely the processes of transfer to living matter.

For a more detailed study, we propose a method associating a hydrodynamic, hydrosedimentary and biogeochemical model such as MARS3D/Eco3M to solve in detail the three-dimensional circulation and a much less finite "boxed" model to study the behavior and speciation of the contaminant. The hydrodynamic, sedimentary and biogeochemical model can thus over time provide the flow of water and matter across the boundaries of a limited number of subzones, with several layers over the depth. The study of "biotic" processes could thus be continued in order to complete experiments and in situ measurements and to analyze their respective importance according to the zones, the seasons, the annual trends and their sensitivity to the hypotheses and the parameters chosen to describe them.

\section{Conclusions}

The developed coupled 3D model MARS3D/Eco3M-MED/PCB have been applied to the studies of the PCB bioaccumulation through GoL trophic chain. The properties of the hydrophobic congener CB153 have been considered in this model.

First, model outputs have been compared to the available in-situ data for two plankton size classes and for suspended solids in two contrasting seasons. Even though it still has some defects related to the modeled period and a scarce available data, the model has shown its capacity to reproduce the good orders of magnitude.

Then, different space-temporal distributions of concentrations and stocks of CB153 associated to different compartments (living and non-living) have 
been analysed in this work. Several key points can be highlighted from this study :

- The Rhone River outflows play an important role in the organism contamination in the coastal zone of GoL. Whereas the atmospheric depositions are rather more important in the offshore zones.

- Rhone River flooding events are followed by the highest food-web contamination. Contaminants discharged from the Rhone transit through the western part of GoL and to the south. However, the highest organism CB153 concentrations are situated mostly in the Rhone River plume zone within the first $20 \mathrm{~m}$ from the surface.

- The quantity of contaminant available in water depend on the kinetics of desorption of the $\mathrm{PCB}$ and its sorption coefficient with respect to the different fractions of matter that settle towards the bottom. These data are important only in the coastal zone and close to the plume. The first sensitivity tests have been performed in this work to study the impact of the different sorption kinetic rate for SPM. However, such SPM sorption kinetic rate change revealed nonlinear SPM and zooplankton stock changes. Therefore this parameter needs to be studied more in detail in the future.

- The amount of contaminant available for transfer to the trophic chain depend also on the sediment transport processes that cause retention of part of the hydrophobic contaminant in the pro delta sediments. This application has shown the need to better reproduce these hydrosedimentary processes.

- The transfer of the available contaminant to bacteria and phytoplankton species is mainly related to the biomass present in the water column and to the sorption coefficient defining the contaminant's ability to adsorb through the surface of organisms and to diffuse into the cells. Since bacteria is mostly represented in GoL during almost all the year - it is the main first level having higher CB153 concentrations and stocks which are further transferred to zooplankton through grazing.

- The transfer of the available contaminant to zooplankton species is linked to the biomass present in the water column and to the transfer fluxes (adsorption and absorption) between the different functional groups of the Eco3M-MED biogeochemical model. This study shows that, for copepods, the absorption fluxes (grazing) are rather higher than the passive sorption fluxes, which are themselves linked to the poorly known sorption coefficient. In order to show the zooplankton 
sorption coefficient change on total stock and concentration of living CB153 to two additional scenarios have been performed. The sensitivity test showed that the sorption coefficient increase lead to strong CB153 copepod increase (about 50\%) especially in the Rhone River plume.

The coupled 3D model attempts to satisfy a large number of specifications that require simulation and understanding of the processes of different disciplines on different scales. Simplifications have been made at the outset to limit computation time (sedimentary model for example) but even if computing means and parallelization techniques become more and more efficient, computing times quickly become limiting to perform full sensitivity tests or simulate longer periods of time.

Such an approach remains a powerful and useful tool to study the effects of a better quantification of a particular process and forcing on the overall dynamics of the contaminant. This is true especially in coastal regions subject to significant spatial gradients and inputs. The next step would be to study contamination fluxes in the different zones of the water column and sediment (for example in photic layer and layer below, sediment layer) which have different physical and biogeochemical properties.

\section{Acknowledgements}

The present research is part of the project COSTAS("Trophic contaminants in the system : phytoplankton, zooplankton, anchovy, sardine"), funded by the French ANR/CES and IFREMER. Part of this research is also a contribution to the Labex OT-Med (no. ANR-11-LABX-0061) funded by the French Government" Investissements d'Avenir" program of the French National Research Agency (ANR) through the A*MIDEX project(no ANR11-IDEX-0001-02). We thank Capucine Mellon-Duval (Ifremer-Sete) - ANR "Merlumed" projet coordinator and also Xavier Bodiguel for sharing their data on CB153 measurements in the GoL.

\section{References}

[1] Achman D.R., Hornbuckle K.C.,Eisenreich C.J., 1993. Volatilization of Polychlorinated Biphenyls from Green Bay, Lake Michigian. Environ. Sci. Technol., Vol. 27, No. 1 : 75-87.

[2] Alekseenko E., Raybaud V., Espinasse B., Carlotti F., Queguiner B., Thouvenin B., Garreau P., Baklouti M., 2014. Seasonal dynamics and 
stoichiometry of the planktonic community in the NW Mediterranean Sea : a 3D modeling approach Ocean Dynamics 64(2) :179-207

[3] André G., Garreau P., Garnier V., Fraunié P., 2005. Modeled variability of the sea surface circulation in the North-western Mediterranean Sea and in the Gulf of Lions. Ocean Dyn 55 :294-308

[4] André G., Garreau P., Fraune P., 2009. Mesoscale slope current variability in the Gulf of Lions. Interpretation of in-situ measurements using a three-dimensional model. Cont Shelf Res 2 :407-423

[5] Auger P.A., Diaz F., Ulses C., Estornel C., Neveux J., Joux F., Pujo-Pay M., Naudin J.J., 2011. Functioning of the planktonic ecosystem on the Gulf of Lions shelf (NW Mediterranean) during spring and its impact on the carbon deposition : a field data and 3-D modeling combined approach. Biogeosciences 8 :3231-3261

[6] Baklouti M., Diaz F., Pinazo C., Faure V., Quequiner B., 2006a. Investigation of mechanistic formulations depicting phytoplankton dynamics for models of marine pelagic ecosystems and description of a new model. Prog Oceanogr $71: 1-33$

[7] Baklouti M., Faure V., Pawlowski L., Sciandra A., 2006b. Investigation and sensitivity analysis of a mechanistic phytoplankton model implemented in a newmodular tool (Eco3M) dedicated to biogeochemical modelling. Prog Oceanogr $71: 34-58$

[8] Baklouti M., Chevalier C., Bouvy M., Corbin D., Pagano M., Troussellier M., Arfi R., 2011. A study of plankton dynamics under osmotic stress in the Senegal River Estuary, West Africa, using a 3D mechanistic model. Ecol Model 222(15):2704-2721

[9] Ball W.P. and Roberts P.V., 1991. Long term sorption of halogenated organic chemicals by aquifer material 2. Intraparticle diffusion. Environ. Sci. Technol. 25(7) : 1237-1249.

[10] Berrojalbiz N., Castro-Jiménez J., Mariani G., Wollgast J., Hanke G., and Dachs J., 2014. Atmospheric occurrence, transport and deposition of polychlorinated biphenyls and hexachlorobenzene in the Mediterranean and Black Seas. Atmos. Chem. Phys., 14, 8947-8959, 2014 
[11] Blumberg A.F. and Mellor G.L., 1986. A description of a ThreeDimensional Coastal Ocean Circulation Model, Geophysical Fluid Dynamics Program, Princeton Univ., Princeton, New Jersey, 1-16.

[12] Bondiguel X., 2008. PhD thesis : Caractérisation et modélisation des processus de bioaccumulation des PCB chez le merlu (Merluccius merluccius) du golfe du Lion.

[13] Bold S., Liedl R., Grathwohl P., 2003. Enhancement of solute spreading in soils due to particle-facilitated transport and preferential flow. Reactive Transport in Soil and Groundwater pp 157-169.

[14] Borgå K., Di Guardo A., 2005. Comparing measured and predicted PCB concentrations in Arctic seawater and marine biota. Sci Total Environ. 2005 Apr $15 ; 342(1-3): 281-300$.

[15] Borja J.,Marie-Teleon D., Auresenia J., Gallardo S., 2005. Polychlorinated biphenyls and their biodegradation. Process Biochem. 40 : 19992013.

[16] Burkhard L. P., 2000. Estimating dissolved organic carbon partition coefficients for nonionic organic chemicals, Environ. Sci. Technol., 34, 4663-4667, doi :10.1021/es001269l.

[17] Cailleaud K., Forget-Leray J., Souissi S., Hilde D., LeMenach K., Budzinski H., 2007. Seasonal variations of hydrophobic organic contaminant concentrations in the water-column of the Seine Estuary and their transfer to a planktonic species Eurytemora affinis (Calanoïda, copepode). Part 1 : PCBs and PAHs. Chemosphere 70, 270-280.

[18] Campens J., Mackay D., 1997. Fugacity-Based Model of PCB Bioaccumulation in Complex Aquatic Food Webs. Environ. Sci. Technol. 1997, $31,557-583$.

[19] Castro-Jiménez J., Dueri S., Eisenreich S. J., Mariani G., Skejo G., Umlauf G.,and Zaldívar J.M., 2009. Polychlorynated biphenyls (PCBs) in the atmosphere of sub-alpine northern Italy. Environment Pollution, 157, 1024-1032. 
[20] Castro-Jiménez J., Mariani G., Vives-Robio I., Skejo H., Umlauf G., Zaldivar Comenges J., Dueri S., Messiaen G., Laugier T., 2011. Atmospheric concentrations, occurrence and deposition of persistent organic pollutants (POPs) in a Mediterranean coastal site (Etang der Tau, France).ENVIRONMENTAL POLLUTION vol. 159 no. 7 p. 1948-1959

[21] Churchill M.A, Elmore H.L., and Buckingham R.A. 1962. Predictions of Stream Reaeration Rates, J. Sanitary Eng., ASCE SA4 :1, Proc paper3199.

[22] De Laender F., Soetaert K., Middelburg J.J., 2010. Inferring chemical effects on carbon flows in aquatic food webs : methodology and case study. Environ Pollut 158 :1775 - 1782. doi :10.1016/j.envpol.2009.11.009

[23] Del Vento S. and Dachs J., 2002. Prediction of up take dynamics of persistent organic pollutants by bacteria and phytoplankton. Environmental Toxicology and Chemistry 21, 2099-2107.

[24] Doney S., S. C. Doney, Lindsay K., Caldeira K., Campin J.-M., Drange H., Dutay J.-C., Follows M., Gao Y., Gnanadesikan A., Gruber N., Ishida A., Joos F., Madec G., Maier-Reimer E., Marshall J. C., Matear R. J., Monfray P., Mouchet A., Najjar R., Orr J. C., Plattner G.K., Sarmiento J., Schlitzer R., Slater R., Totterdell I. J., Weirig M.-F., Yamanaka Y.,and Yool A., 2004. Evaluating global ocean carbon models : The importance of realistic physics, Global Biogeochem. Cycles, 18, GB3017, doi :10.1029/2003GB002150.

[25] Dufois F, Garreau P, Le Hir P, and Forget P 2008. Wave and current induced bottom shear stress distribution in the Gulf of Lions. Continental Shelf Research 28 (15) : 1920-1934.

[26] Eisenhauer N., Milcu A., Nitschke N., Sabais A.C.W., Scherber C., Scheu S., 2009. Earthworm and belowground competition effects on plant productivity. Oecologia 161 :291-301

[27] Falandysz J., Wyrzykowska B., Warzocha J., Barska I., GarbacikWesolowska A., Szefer P., 2004. Organochlorine pesticides and PCBs in perch Perca fluviatilis from the Odra/Oder river estuary, Baltic Sea. Food Chem. 87, 17-23. 
[28] Fan C.-W. and Reinfelder J.R., 2003. Phenanthrene Accumulation Kinetics in Marine Diatoms. Environmental Science and Technology 37(15) :3405-12, DOI : 10.1021/es026367g

[29] Fontana C., Grenz C., Pinazo C., Marsaleix P., Diaz F., 2009. Assimilation of SeaWiFS chlorophyll data into a 3D-coupled physical-biogeochemical model applied to a freshwater-influenced coastal zone. Cont Shelf Res 29(11-12) :1397-1409

[30] Galbán-Malagón C. J., Del Vento S., Cabrerizo A., and Dachs J., 2013. Factors affecting the atmospheric occurrence and deposition of polychlorinated biphenyls in the Southern Ocean. Atmos. Chem. Phys., 13, 12029-12041, 2013, doi :10.5194/acp-13-12029-2013

[31] Gong Y.Y., Depinto J.V., 1998. Desorption rates of two PCB congeners from suspended sediments. II. Model simulation. Water Res. 32, $2518-2532$

[32] IFREMER, 2011. Qualité du Milieu Marin Littoral Bulletin de la surveillance. Edition 2011.

[33] Jurado E., Jaward F. M., Lohmann R., Jones K. C., Simo R., and Dachs J., 2004. Atmospheric dry deposition of persistent organic pollutants to the Atlantic and inferences for the global oceans, Environ. Sci. Technol.,38, 5505-5513.

[34] Karickhoff S. W., Brown D. S. and Scott T. A., 1979. Sorption of hydrophobic pollutants on natural sediments. Wat. Res. 13, 241-248.

[35] Harmelin-Vivien M., Loizeau V., Mellon C., Beker B., Arlhac D., Bodiguel X., Ferraton F., Hermand R., Philippon X., Picard, 2008. Comparison of $\mathrm{C}$ and $\mathrm{N}$ stable isotope ratios between surface and organic matter and phytoplankton in the Gulf of Lions (NW Mediterranean). Continental Shelf Research, 28 : 1911-1919

[36] Lanfranchi A.L., Menone M.L., Miglioranza K.S.B., Janiot L.J., Aizpun J.E., Moreno V.J., 2006. Striped weakfish (Cynoscion guatucupa) : a biomonitor of organochlorine pesticides in estuarine and near-coastal zones. Mar. Pollut. Bull. 52, 74-80. 
[37] Lazure P. and Dumas F., 2008. An external-internal mode coupling for a 3D hydrodynamical model for applications at regional scale (MARS). Adv.Wat. Res. 31 : 233-250.

[38] Le Fouest V., Chami M., and Verney R., 2015. Analysis of riverine suspended particulate matter fluxes (Gulf of Lion, Mediterranean Sea) using a synergy of ocean color observations with a 3-D hydrodynamic sediment transport model, J. Geophys. Res. Oceans, 120, 942-957, doi :10.1002/2014JC010098.

[39] Lee J-F., Chao H-P., Chiou C.T. Manes M., 2004. Turbulence Effects on Volatilization Rates of Liquids and Solutes. Environ. Sci. Tachnol., $38: 4327-4333$.

[40] Mauriac R., Moutin T., Baklouti M., 2011. Accumulation of DOC in low phosphate low chlorophyll (LPLC) area : is it related to higher production under high N :P ratio? Biogeosciences 8 :933-950. doi :10.5194/bg8-933-2011

[41] Le Hir P., Cayocca F., Waeles B., 2011. Dynamics of sand and mud mixtures : a multiprocess-based modelling strategy. Cont Shelf Res 31 :S135S149.

[42] Lévy M., 2003. Mesoscale variability of phytoplankton and of new production : Impact of the large scale nutrient distribution, J. Geophys. Res., Vol 108, C11, 3358 10.1029/2002JC001577

[43] Liss P. S. and Slater P. G., 1974. Flux of gases across the air-sea interface. Nature, 247, 181-184.

[44] Lynn S.G., Price D.J., Birge W.J., Kilham S.S., 2007. Effect of nutrient availability on the uptake of PCB congener 2,2',6,6' -tetrachlorobiphenyl by a diatom (Stephanodiscus minutulus) and transfer to a zooplankton (Daphnia pulicaria). Aquat Toxicol $83: 24-32$.

[45] Magnusson K., Ekelund R., Grabic R., Bergqvist P.A., 2006. Bioaccumulation of PCB congeners in marine benthic infauna.Mar Environ Res. 2006 May;61(4) :379-95. Epub 2006 Jan 18. 
[46] Nicolle A., Garreau P., Liorzou B., 2009. Modelling for anchovy recruitment studies in the Gulf of Lions (Western Mediterranean Sea). Ocean Dyn 59(6): :953-968

[47] Nizzetto L., Gioia R., Li J., Borgå K., Pomati F., Bettinetti R., Dachs J., Jones K.C., 2012. Biological pump control of the fate and distribution of hydrophobic organic pollutants in water and plankton. Environ. Sci. Technol. 46 (6), 3204-32 11.

[48] Pujo-Pay M., Conan P., Oriol L., Cornet-Barthaux V., Falco C., Ghiglione J.F., Goyet C., Moutin T., Prieur L., 2011. Integrated survey of elemental stoichiometry (C, N, P) from the western to eastern Mediterranean Sea. Biogeosciences 8 :883-899

[49] Schuster S.C., Miller W., Ratan A., Tomsho L.P., Giardine B., Kasson L.R., Harris R.S., Petersen D.C., Zhao F., Qi J., Alkan C., Kidd J.M., Sun Y., Drautz D.I., Bouffard P., Muzny D.M., Reid J.G., Nazareth L.V., Wang Q., Burhans R., Riemer C., Wittekindt N.E., Moorjani P., Tindall E.A., Danko C.G., Teo W.S., Buboltz A.M., Zhang Z., Ma Q., Oosthuysen A., Steenkamp A.W., Oostuisen H., Venter P., Gajewski J., Zhang Y., Pugh B.F., Makova K.D., Nekrutenko A., Mardis E.R., Patterson N., Pringle T.H., Chiaromonte F., Mullikin J.C., Eichler E.E., Hardison R.C., Gibbs R.A., Harkins T.T., Hayes V.M., 2010. Complete Khoisan and Bantu genomes from southern Africa. Nature. Feb 18 ;463(7283) :943-7. doi : 10.1038/nature08795.

[50] Oschlies A., 2002. Nutrient supply to the surface waters of the North Atlantic : A model study, J. Geophys. Res., 107(C5), 3046, doi :10.1029/2000JC000275.

[51] Pinazo C., Fraysse M., Doglioli A., Faure V.M., Pairaud I, Petrenko A., Thouvenin B., Tronczynski J., Verney R., Yohia C., 2013. MASSILIA : Modélisation de la baie de Marseille : Influence des apports Anthropiques de la métropole sur l'écosystème marin. http ://archimer.ifremer.fr/doc/00145/25592/

[52] Schaefer K., Zhang T., Bruhwiler L. and Barrett A.P., 2011. Amount and timing of permafrost carbon release in response to climate warming Tellus Series B : Chem. Phys. Met. 63 165-80 
[53] Schwarzenbach R.P., Gschwend P.M., Imboden D.M., 2003. Environmental Organic Chemistry. Wiley.

[54] Sobek A., Gustafsson O., 2004. Latitudinal fractionation of polychlorinated biphenyls in surface seawater along a $62^{\circ} \mathrm{N}-89^{\circ} \mathrm{N}$ transect from the southern Norwegian Sea to the North Pole area. Environ Sci Technol $38: 2746-51$.

[55] Staundinger J. and Roberts P.V., 2001. "A critical compilation of Henry's law constant temperature dependence relations for organic compounds in dilute aqueous solutions", Chemosphere. Vol. 44, p. 561.

[56] Strady E., Harmelin-Vivien M., Chiffoleau J.-F., Veron A., Tronczynski J., Radakovitch O., 2015. 210Po and 210Pb trophic transfer within the phytoplankton-zooplankton-anchovy/sardine food web : a case study from the Gulf of Lion (NW Mediterranean Sea). Journal Of Environmental Radioactivity, 143, 141-151. http ://doi.org/10.1016/j.jenvrad.2015.02.019

[57] The Mermex group : Durrieu de Madron X., Guieu C., Sempéré R., Conan P., Cossa D., D'Ortenzio F., Estournel C., Gazeau F., Rabouille C., Stemmann L., Bonnet S., Diaz F., Koubbi P., Radakovitch O., Babin M., Baklouti M., Bancon-Montigny C., Belviso S., Bensoussan N., Bonsang B., Bouloubassi I., Brunet C., Cadiou J.-F., Carlotti F., Chami M., Charmasson S., Charrière B., Dachs J., Doxaran D., Dutay J.-C., Elbaz-Poulichet F., Eléaume M., Eyrolles F., Fernandez C., Fowler S., Francour P., Gaertner J.C., Galzin R., Gasparini S., Ghiglione J.-F., Gonzalez J.-L., Goyet C., Guidi L., Guizien K., Heimbürger L.-E., Jacquet S.H.M., Jeffrey W.H., Joux F., Le Hir P., Leblanc K., Lefèvre D., Lejeusne C., Lemé R., Loÿe-Pilot M.-D., Mallet M., Méjanelle L., Mélin F., Mellon C., Mérigot B., Merle P.-L., Migon C., Miller W.L., Mortier L., Mostajir B., Mousseau L., Moutin T., Para J., Pérez T., Petrenko A., Poggiale J.-C., Prieur L., Pujo-Pay M., Pulido-Villena, Raimbault P., Rees A.P., Ridame C., Rontani J.-F., Ruiz Pino D., Sicre M.A., Taillandier V., Tamburini C., Tanaka T., Taupier-Letage I., Tedetti M., Testor P., Thébault H., Thouvenin B., Touratier F., Tronczynski J., Ulses C., Van Wambeke F., Vantrepotte V., Vaz S., Verney R., 2011. Marine ecosystems' responses to climatic and anthropogenic forcings in the Mediterranean. Prog. Oceanogr. 91. doi :10.1016/j.pocean.2011.02.003. 
[58] Tiano M., Tronczynski J., Harmelin-Vivien M., Tixier C., Carlotti F., 2014. PCB concentrations in plankton size classes, a temporal study in Marseille Bay, Western Mediterranean Sea. Mar. Pollut. Bull. 89, 331339. http ://dx.doi.org/10.1016/j.marpolbul.2014.09.040

[59] Totten L.A., Brunciak P.A., Gigliotti C.L., Dachs J., Glenn T.R., Nelson E.D., Eisenreich S. J., 2001. Dynamic air-water exchange of polychlorinated biphenyls in the New York-New Jersey Harbor Estuary. Environ Sci Technol $35: 3834-40$.

[60] Tronczynsky J., Chiffoleau J.-F., 2011. COSTEAU 5 cruise, RV L'Europe, http ://dx.doi.org/10.17600/11060010

[61] Tronczynsky J., Tixier C., Cadiou J.F.,Belly N., Heas-Moisan K., Castelle S., Migon C.,Dufour A., Merieau R., 2012. Apports rhodaniens et suivi atmosphérique des contaminants organiques persistants (PCB, PBDE, HAP, PCDD/F) dans le Golfe du Lion (2009-2010). Rapport Ifremer $\mathrm{N}^{o} \mathrm{RST}-\mathrm{RBE} / \mathrm{BE} / \mathrm{LBCO} / 2012-04$

[62] UNEP,1996, A Survey of Geographic Information Systems \& Image Processing Software 1995 : UNEP Publication.

[63] UNEP, 2002. Atlas of International Freshwater Agreements. UNEP/GRID Sioux Falls in cooperation with Oregon State University.

[64] Verney R., Jany C., Thouvenin B., Pairaud I., Vousdoukas M., Pinazo C., Ardhuin F., and Cann P., 2013. Sediment transport in the bay of Marseille : Role of extreme events, Proceedings of Coastal Dynamics 2013, in 7th International Conference on Coastal Dynamics, 24-28 June 2013, pp. 1811-1822, Arcachon, France. [Available at http ://archimer.ifremer.fr/doc/00204/31515/.]

[65] Waeles B., Le Hir P., Lesueur P., Delsinne N., 2007. Modelling sand/mud transport and morphodynamics in the Seine river mouth (France) : an attempt using a process-based approach. Hydrobiologia (2007) 588 : 6982.

[66] Waeles B., Le Hir P., Lesueur P., 2008. A 3D morphodynamic processbased modelling of a mixed sand/mud coastal environment : the Seine 
estuary, France. Sediment and Ecohydraulics : INTERCOH 2005, T. Kusuda, H. Yamanishi, J. Spearman and J.Z. Gailani (Eds), Proceedings in Marine Science 9, Elsevier, 477-498.

[67] Wallberg P., Bergqvist P.-A. and Andersson A., 1997. Potential importance of protozoan grazing in the accumualtion of PCBs in the pelagic food web. Hydrobiologia $357: 53-62$.

[68] Wallberg P., Bergqvist P. A. and Anderson A. (1997) Potential importance of protozoan grazing on the accumulation of polychlorinated biphenyls in the pelagic food web. Hydrobiologia 357, 53-62.

[69] Wallberg P., Andersson A., 1999. Determination of adsorbed and absorbed polychlorinated biphenyls (PCBs) in seawater microorganisms. Marine Chemistry 64 : 287-299.

[70] Wania F. and Mackay D., 1995. A global distribution model for persistent organic chemicals. Sci. Total Environ. 160/161 : 211-232.

[71] Wen C-G., Kao J-F., Wang L.K., Liaw C-C, 1984. Effect of salinity on reaeration coefficient of receiving waters. Wat. Sci. Tech., 16, 139-154. 